\author{
UNIVERSIDADE DE SÃO PAULO \\ FACULDADE DE ODONTOLOGIA DE BAURU
}

LORENA DE MELLO ALCÂNTARA GARRIDO

Influence of the polishing technique on the roughness and profile of bisacryl-based materials

Influência da técnica do polimento na rugosidade superficial e perfilometria de materiais à base de resina bisacrílica 

Influence of the polishing technique on the roughness and profile of bisacryl-based materials

Influência da técnica do polimento na rugosidade superficial e perfilometria de materiais à base de resina bisacrílica

Dissertação constituída por artigo apresentada a Faculdade de Odontologia de Bauru da Universidade de São Paulo para obtenção do título de Mestre em Ciências Odontológicas Aplicadas, na área de concentração Dentística.

Orientador: Prof ${ }^{\mathrm{D}}$. Dr. Adilson Yoshio Furuse

Versão Corrigida 


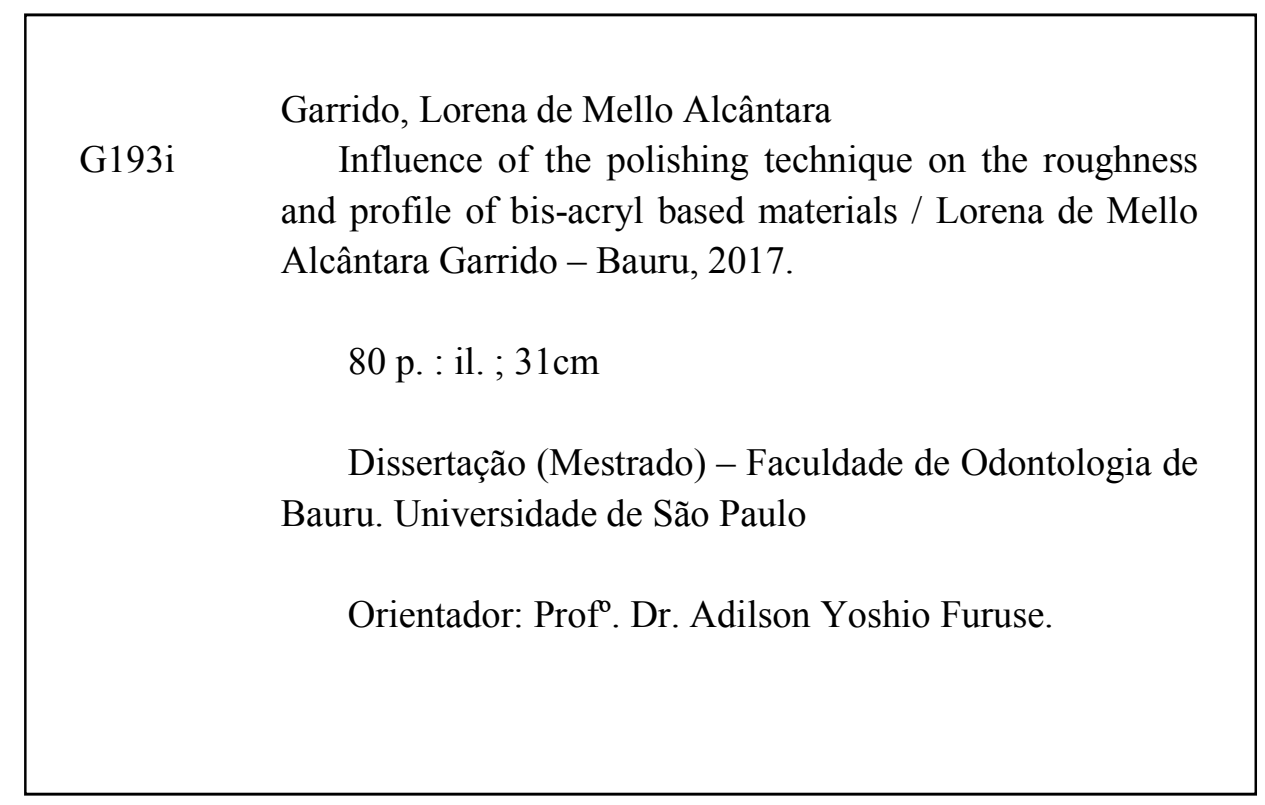

Nota: A versão original desta dissertação encontra-se disponível no Serviço de Biblioteca e Documentação da Faculdade de Odontologia de Bauru - FOB/USP.

Autorizo, exclusivamente para fins acadêmicos e científicos, a reprodução total ou parcial desta dissertação por processos fotocopiadores e outros meios eletrônicos.

Assinatura: 
FOLHA DE APROVAÇÃO 


Se hoje, eston aqui... é por nós!! Agradeço à Deus por ter me dado a felicidade de viver esse sonho.

E, junto comigo sempre você "Gordo", não caminhei sozinha, tivemos nossas vidas unidas, pela familia que formamos.

obrigada pelo apoío, pelo esforço, pelo incentivo, por acreditar que seríamos capazes de fazer juntos. Juntos, eu você, nossos filhos,

Bibiana e joão, nossa família, te amo! 

AGRADECIMENTOS 



\section{AGRADECIMENTOS}

Há exatos 20 anos, sonhei em estar aquí!

Por isso talvez a dimensão dos sentimentos seja inexplicável, uma mistura de emoção, as lágrimas vieram abaíxo, junto com uma alegría absurda, quando soube da aprovação para cursar o mestrado na FOBUSP, o meu sonho de 20 anos atrás, estava começando a se tornar real, demorei para acreditar, momento indescritivel.

Agradeço...

ม̀ Deus, sempre!!!

À minha familía ....

Aos meus pais Luiz Carlos de Souza Alcântara (in memoriam) e Raimunda Fátima de Mello Alcântara por terem me proporcionado, uma vida, valores dignos, responsabilidades, e os estudos, aos meus irmãos Patricia e Preto. 

Aos meus orientadores...

Durante meu curso de mestrado, tive a honra e o privilégio de ter dois orientadores, Prof. Dr. Jose Mondelli, meu primeiro orientador, fíquei lisonjeada, sempre me dando incentivo, me ensinando, me orientando durante todo o meu curso, Mestre que a cada día aprendo a admirar e respeitar muito. Gratidão, respeito, admiração, carinho, essas são as palavras que define todo o meu sentimento pelo Sr. Prof. Mondelli. Se eu estou aqui hoje, agradeço ao Senhor, obrigada por ter acreditado em mim, antes de mim mesma. $\mathcal{E}$ também ao prof. $\mathcal{D} r$. Adilson Yoshio furuse, meu atual orientador, pelos ensinamentos, a colaboração na pesquísa.

Aos professores...

Aos professores do Departamento de Endodontia, Dentística e Materiais Odontológicos, por terem explanado suas experiêncías, seus confecimentos, suas habilidades práticas, para melhorar nosso desempenho profíssional. Crescemos e aprendemos muito. Muito obrigada Mestres. 

Em especial ao Prof. Dr. Rafael Francisco Lía Mondelli, as palavras são poucas, ou quase sem significado, perto do que o Senhor representa para mim, um ser humano admirável, de um coração enorme, sou muito grata por ter partícipado da turma de Atualização em 2014, que foi lá que tudo começou. Aonde eu estiver, sempre, sempre, irei lembrar da familia Mondelli. Muito, obrigada, tem minha gratidão e meu respeito sempre.

$\mathcal{A}$ todos os alunos da pós-graduação...

Agradeço imensamente, a ajuda no começo de tudo, dos alunos do mestrado da turma de 2013 e 2014, hoje, doutorandos, que foram de extrema importância, dando o ponta pé inicial para minha caminhada aqui dentro da FOBUSP. Agradeço a cada um de vocês por tudo, cada um com o seu momento, no seu tempo, e do seu jeito. Amígos de conversas, amigos de risadas, amigos de clinica, amigos de laboratório, amigos do departamento.

Em especial ...

Ao Rafa Menezes, Odair, Fábio Antônio, Marília Velo, Cassí, Lê Brianezzi que sempre me ajudaram ou me aconselharam, muito obrigada. 

Agradeço aos amígos, em especial ...

A principal de todas, a doutoranda, Ana Flávía Soares, ou como a chamo "Aninha", um anjo na minha vida, atenciosa, paciente, foi o meu guia, minha professora, minha base, minha direção. O que sería de mim, sem seus "vídeos" e seus "áudios"? Responsável direta por eu estar aqui hoje. Serei eternamente grata.

Allison, meu Graço direito no laboratórío, sou imensamente grata, pelos dias, pelas noites, pelos finais de semana, feriados, que estava comigo no Caboratório de Materiais Dentários, me ajudando, muito obrigada.

丸̀ Fer Sandes, e o que falar diante de tanta bondade? Só tenho a agradecer a você Fer. Que Deus possa the presentear com pessoas boas, que possam somar com seu britho, com sua força, com o seu esforço para que você consiga realizar todos os seus sonhos e ser a "best teacher" que você sempre sonhou. Eu sei que você vaí chegar lá. Muito obrígada.

À Tamis, você foi de uma extrema importância para eu estar aquí hoje. Minha eterna gratidão

ม̀ minha Luara, que é uma benção na minha vida, muito obrigada, pelos conselhos, pelos ensinamentos, pelo ombro amigo, pela sinceridade, pelos puxões de orelha, pela companhía, pela amizade. 

À Loira linda Ligía Andreatta, pela doçura, por explicações que muitas vezes foram por áudio no celular, ou na clinica, e quantos ensinamentos hein? Como você com seu sorríso meigo, torna as coísas mais fáceis.

Ao Tíco, desde o início, do meu lado, um amígo do Peru, um companheiro, um ser iluminado, de sorriso de molar a molar. Obrigada por deixar eu fazer parte da sua vida em Bauru.

À Baratis, essa Goiana cheía de vida, muito, muito feliz em poder contar com você e ter você por perto.

Às amigas Nati Galvão, Puccha, obrigada meninas, pelos rísos, pela companhía, pela força, pelo grupo, pelos incentivos, pela amizade pra vidaaa!

丸̀ minha turma, Mestrado 2015...

Cada um veío de um lugar diferente, mas mesmo com tantas diferenças, tive o privilégio de poder contar com o apoío de todos.

Muito obrigada...

Angélica, Fabricia, Fernanda, Giovanna, Isa, Lígia, Naiara e Natália, Mauro por tudo. 

Aos funcionários do Departamento de Dentística e Materiais Odontológicos, em especial à Audritcha, Sweet, Chay e ao grande Nerso, Sandrinha e Alcides ninja, pela ajuda, muitas vezes fora de hora, obrigada pela confíança, pelo carinho, pelo apoío, não esquecerei de vocês. $\mathcal{E}$ as meninas da clinica da pós-graduação, Cleusitcha e Hebitcha, muito obrigada.

Agradeço à Faculdade de Odontología de Bauru, da Universidade de São Paulo, em nome de sua diretora Prof. ${ }^{a}$ Dra María Aparecida Moreira Machado.

Ao Prof. Dr. Heitor Marques Honório, pela paciência e ajuda inestimável com a análise estatística deste trabalho, muito obrígada.

À Coordenação de Aperfeiçoamento de Pessoal de $\mathcal{N} i ́ v e l$ Superior (Capes) e ao Conselho Nacional de Desenvolvimento Cientifico e Tecnológico (CNDP) pelo incentivo em meu trabalho e dar o suporte financeiro necessário para a realização deste estudo.

Aos demais que direta ou indiretamente contribuiram para a realização deste trabalho, o meu muito obrigada. 

ABSTRACT

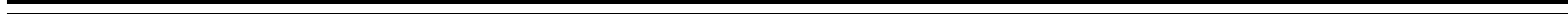





\section{ABSTRACT \\ Influence of the polishing technique on the roughness and profile of bis-acryl-based materials}

Statement of the problem. The choice of technique and material for making provisional restorations is important. The material must have enough strength to withstand the masticatory loads without suffering deformation or fracture and its surface must have good finishing and polishing to reduce biofilm accumulation.

Objective. The aim of this study was to investigate what is the best polishing protocol for different bis-acryl materials with the intention to obtain a smooth surface.

Materials and methods. A total of 104 samples were made $(15 \mathrm{~mm}$ long $\mathrm{x} 5 \mathrm{~mm}$ wide $\mathrm{x} 4 \mathrm{~mm}$ high) and were divided into three study factors: material (Protemp 4, Structur 3, Dencor, Z350XT), polishing (Sof-Lex Pop On and Sof-Lex Spiral discs) and period (initial, postpolishing, post-brushing). Thirteen samples were made per material group, and at each step, a sample was randomly taken for the purpose of submitting to scanning electron microscopy (SEM) analysis, totaling 24 samples to be submitted to this test, and thus, resulting in 80 samples to be brushed, and 10 samples per group for statistical analysis $(n=10)$. In all samples, surface roughness readings $(\mu \mathrm{m})$ were performed at all periods, that is, after they were made, after polishing and after brushing through the rugosimeter (Hommel tester). At the end, the 80 samples were read in a profilometer for analysis of surface wear. The results for the roughness were submitted to ANOVA for three criteria followed by the Tukey's test ( $\alpha=0.05$ ), and for the surface wear test, the results were submitted to ANOVA for two criteria followed by the Tukey`s test $(\alpha=0.05)$.

Results. Protemp 4 bis-acryl showed higher values of surface roughness when polished with Sof-Lex Spiral discs $(0.284 \mu \mathrm{m})$ when compared to Sof-Lex Pop On discs polishing $(0.075$ $\mu \mathrm{m})$. After brushing, there was an increase of surface roughness for both types of polishing. Sof-Lex Spiral discs $(0.375 \mu \mathrm{m})$ and Sof-Lex Pop On discs $(0.359 \mu \mathrm{m})$, but with no significant differences $(p>0.05)$. For the surface wear results, there was no statistical difference between the groups: Protemp 4 bis-acryl resin with Sof-Lex Pop On polishing $(13.95 \mu \mathrm{m})$ and polishing with the Sof-Lex Spiral discs $(14.91 \mu \mathrm{m})$ and the Z350XT composite resin group polished with the two polishing systems - Sof-Lex Pop On and Sof-Lex Spiral $(12.61 \mu \mathrm{m}, 12.70 \mu \mathrm{m}$, respectively). Structur 3 bis-acryl resin showed lower surface roughness results when polished with Sof-Lex Pop On discs $(0.113 \mu \mathrm{m})$ compared to Sof-Lex Spiral discs $(0.223 \mu \mathrm{m})$. For the surface wear results, there was no difference between the groups of the Structur 3 bis-acryl resin, but the values for both the polished group with Sof-Lex Pop On discs $(15.77 \mu \mathrm{m})$ and 

the group polished with the Sof-Lex discs Spiral $(15.40 \mu \mathrm{m})$ were very close to the values of the group of the Protemp 4 bis-acryl resin and the Z350XT composite resin group, with statistical difference. The two tested bis-acryl resins, the Protemp 4 and Structur 3 in the two polishing systems, showed better surface roughness values $(\mathrm{Ra})$ and lower surface wear values than the Dencor acrylic resin. Dencor acrylic resin group showed the highest values of surface roughness at all times. However, after polishing and brushing, the surface roughness presented lower values, when compared to Ra initial values, but this material showed the highest surface wear values $(31.21 \mu \mathrm{m})$. The resin composite group Z350XT which polishing procedure was Sof-Lex Pop On discs showed lower values $(0.039 \mu \mathrm{m})$. There were no statistically significant differences in surface roughness at all periods and the surface roughness increased after brushing, followed by lower values also for surface wear $(12.61 \mu \mathrm{m})$.

Conclusion. By polishing it is possible to improve the surface roughness of the resinous materials, however, the technique, the operator, the materials to be polished and the finishing and polishing system are directly correlated. For the present study, the system that obtained the best results was the Sof-Lex Pop On discs, and the bis-acryl resin that presented the lowest Ra number was the Structur 3 bis-acryl resin. For surface wear, the Structur 3 bis-acryl resin showed higher values compared to the results of the Protemp 4 bis-acryl resin group, which, in turn, showed surface wear values close to that of the Z350 XT composite resin group.

Key words: Acrylic resin. Bis-acryl. Brushing. Resin Composite. Polishing. Roughness. 

RESUMO

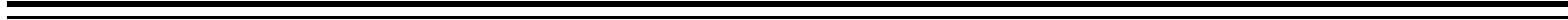





\section{RESUMO}

\section{Influência da técnica de polimento na rugosidade superficial e perfilometria de materiais à base de resina bisacrílica}

Problematização. É de grande importância a escolha da técnica e do material a serem utilizados para a confecção das restaurações provisórias. O material deve apresentar espessura suficiente e resistência para suportar as cargas mastigatórias sem sofrer deformação ou fratura, bem como, sua superfície deve apresentar um bom acabamento e polimento, reduzindo assim o acúmulo de biofilme, facilitando a higienização pelo paciente.

Objetivo. Investigar qual o melhor protocolo de polimento para as diferentes resinas bisacrílicas com a intenção de obter uma superfície lisa.

Material e métodos. Um total de 104 amostras foram confeccionadas (15mm de comp. x 5mm de largura $\mathrm{x} 4 \mathrm{~mm}$ de altura) e foram divididos em três fatores de estudo: material (Protemp 4, Structur 3, Dencor, Z350XT), polimento (discos Sof-Lex Pop On e Sof-Lex Spiral) e período (inicial, pós polimento, pós escovação). Foram confeccionadas 13 amostras por grupo de material, sendo que em cada etapa foi retirado uma amostra aleatoriamente com a finalidade de submeter à análise de microscopia eletrônica de varredura (MEV), totalizando 24 amostras para serem submetidas a este teste, e assim, resultando em 80 amostras para serem escovadas, e em 10 amostras por grupo para análise estatística $(\mathrm{n}=10)$. Em todas as amostras foram realizadas leituras $(\mu \mathrm{m})$ da rugosidade de superfície $(\mathrm{Ra})$ em todos os períodos, ou seja, logo após serem confeccionadas, após o polimento e após escovação, através do rugosímetro (Hommel tester). Ao final, as 80 amostras foram submetidas a leitura no perfilômetro, para análise do desgaste superficial. Os resultados para a rugosidade foram submetidos a ANOVA a três critérios seguido pelo teste de Tukey $(\alpha=0,05)$. E para o desgaste superficial os resultados foram submetidos a ANOVA a dois critérios seguido pelo teste de Tukey $(\alpha=0,05)$.

Resultados. A resina bisacrílica Protemp 4 mostrou maiores valores de rugosidade superficial (Ra) quando polidos com os discos Sof-Lex Spiral (0,284 $\mu \mathrm{m})$, quando comparado ao polimento com discos Sof-Lex Pop On $(0,075 \mu \mathrm{m})$, após a escovação houve aumento da rugosidade superficial para ambos os tipos de polimentos, tanto os discos Sof-Lex Spiral $(0,375 \mu \mathrm{m})$ quanto para o polimento com os discos Sof-Lex Pop On $(0,359 \mu \mathrm{m})$, mas não houve diferença estatística significativa $(p>0,05)$. Para os resultados de desgaste superficial, não houve diferença estatística entre os grupos: da resina bisacrílica Protemp 4 com polimento Sof-Lex Pop On $(13,95 \mu \mathrm{m})$, e com o polimento com os discos Sof-Lex Spiral $(14,91 \mu \mathrm{m})$ e o grupo da resina composta Z350XT polidos com os dois sistemas de polimento - Sof-Lex Pop On e SofLex Spiral $(12,61 \mu \mathrm{m}, 12,70 \mu \mathrm{m}$ respectivamente). 

A resina bisacrílica Structur 3 mostrou menores valores de rugosidade de superfície quando polidos com os discos Sof-Lex Pop On $(0,113 \mu \mathrm{m})$ em comparação ao polimento com os discos Sof-Lex Spiral $(0,223 \mu \mathrm{m})$. Para os resultados de desgaste superficial, não houve diferença entre os grupos da resina bisacrílica Structur 3, porem os valores tanto para o grupo polido com os discos Sof-Lex Pop On $(15,77 \mu \mathrm{m})$ e o grupo polido com os discos Sof-Lex Spiral $(15,40 \mu \mathrm{m})$ foram bem próximos aos valores do grupo da resina bisacrílica Protemp 4 e ao grupo da resina composta Z350XT, com diferença estatística.

As duas resinas bisacrílicas testadas, a Protemp 4 e a Structur 3 nos dois sistemas de polimentos mostraram melhores valores de rugosidade superficial $(\mathrm{Ra})$ e menores valores de desgaste superficial que a resina acrílica Dencor.

Conclusão. Através do polimento é possível melhorar a rugosidade superficial dos materiais resinosos, entretanto, a técnica, o operador, os materiais a serem polidos e o sistema de acabamento e polimento estão diretamente correlacionados. Para este estudo, o sistema que obteve os melhores resultados foi o dos discos Sof-Lex Pop On, e a resina bisacrílica que apresentou o menor número de Ra foi a resina bisacrílica Structur 3. Para o desgaste superficial a resina bisacrílica Structur 3 mostrou valores maiores comparados aos resultados do grupo da resina bisacrílica Protemp 4, esta, por sua vez, mostrou valores de desgaste superficial próximos ao do grupo da resina composta Z350 XT.

Palavras chave: Resina acrílica. Bisacrílica. Escovação. Resina composta. Polimento. Rugosidade. 



\section{LIST OF FIGURES}

Figure 1. Metallic mold used for samples preparation.

Figure 2. Fig 2, 2A, 2B,2C, 2D 2E - preparation sequence of the bis-acryl resin samples and removal of the metallic matrix

Figure 3. Graphics representing the $\mathrm{Ra}$ values in all times for the different tested materials. Being the group Protemp 4 (A); Structur 3 (B); Dencor (C); Filtek Z350XT (D); Note that the scale at the y-axis changes according to the material.

Figure 4. Bis-acryl resin (Protemp 4) A) Initial Roughness Surface; B) Polishing with Sof-Lex Pop On discs; C) Brushing procedure.

Figure 5. Bis-acryl resin (Protemp 4) A) Initial Roughness Surface; B) Polishing with Sof-Lex Spiral discs; C) Brushing procedure.

Figure 6. Bis-acryl resin (Structur 3) A) Initial Roughness Surface; B) Polishing with Sof- Lex Pop On discs; C) Brushing procedure.

Figure 7. Bis-acryl resin (Structur 3) A) Initial Roughness Surface; B) Polishing with Sof- Lex Spiral discs; C) Brushing procedure.

Figure 8. Acrylic resin group (Dencor) A) Initial Roughness Surface; B) Polishing with Sof- Lex Pop On discs; C) Brushing procedure.

Figure 9. Acrylic resin group (Dencor) A) Initial Roughness Surface; B) Polishing with Sof- Lex Spiral discs; C) Brushing procedure.

Figure 10. Composite resin (Filtek Z350XT) A) Initial Roughness Surface; B) Polishing with Sof-Lex Pop On discs; C) Brushing procedure.

Figure 11. Composite resin (Filtek Z350XT) A) Initial Roughness Surface; B) Polishing with Sof-Lex Spiral discs; C) Brushing procedure. 



\section{LIST OF TABLES}

Table 1 - Materials used on this study......

Table 2 - Groups according to polishing techniques and material 34

Table 3 - Mean and standard deviation of Polishing, Roughness and Wear of the different tested materials ........................................................................ 42 



\section{TABLE OF CONTENTS}

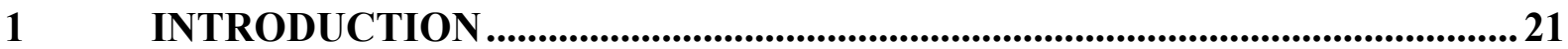

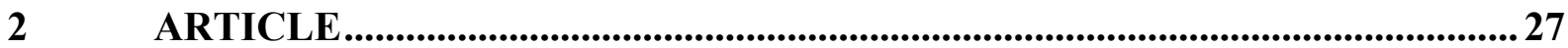

3 DISCUSSION

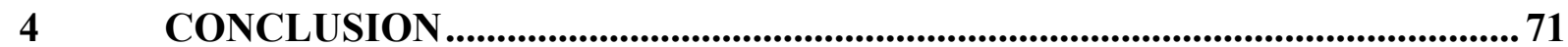

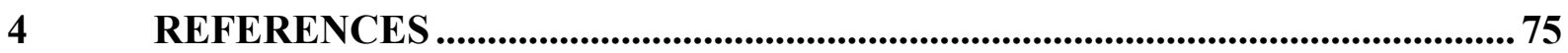



1 INTRODUCTION 



\section{INTRODUCTION}

Dental treatments that demand esthetic and functional restorations with indirect procedures such as ceramic veneers and crowns require the preparation of provisional restorations. However, these provisional restorations can remain in the mouth for longer than expected, until the cementation of the prosthetic restorations. Therefore, provisional materials must present esthetics, strength, and be of easily clinical application. In addition, these materials for temporary restorations must have several colors to allow the reproduction of the tooth structure and provide satisfaction to the patient.

The choice of the technique and materials used for making provisional restorations are very important. The material must have sufficient thickness and strength to withstand the masticatory loads without suffering deformation or fracture, as well as its surface must be submitted to adequate finishing and polishing procedures to reduce biofilm accumulation and facilitate the cleaning by the patient (SCHWEDHELM, 2006; STRASSLER and LOWE, 2011; YAP et al., 1998). Since the biofilm accumulation is harmful to periodontal tissue by generating gingival inflammation, bleeding and gingival recession (WAERHAUG, 1980), finishing and polishing are used to minimize these problems and improve the clinical performance of materials (AVSAR et al., 2015).

Thus, the use of correct finishing and polishing procedures becomes a paramount factor, because they reduce biofilm accumulation, improve the tolerance of the periodontal tissues and increase the resistance of the composite to the impregnation by pigment and wear (RUTKÜNAS et al., 2010; SEN et al., 2002). These procedures make the restoration surface smoothness and more similar to dental enamel (CELIK et al., 2010; MARESCA et al., 2010; SWIFT and PERDIGÃO, 1998). To prevent a significant plaque accumulation, a roughness 
value of $0.2 \mu \mathrm{m}$ is considered ideal (BOLLEN et al., 1997). This value is considered as a parameter and below this value there is lower biofilm accumulation, while above it may cause more accumulation (BOLLEN et al., 1997). With the increased demand for esthetics procedures, laminate veneers are more required to improve the harmony of the smile. Therefore, it became essential to use a provisional restorative material that provides such requirements (YOUNG et al, 2001; WASSEL et al, 2002).

Chemically activated acrylic resins are the most common used materials for making temporary restorations are their main composition is polymethylmethacrylate (GULLER et al, 2005). These resins have some properties that make them good materials to be used until the present day, such as biocompatibility, absence of taste and odor, dimensional stability, good polishing capacity, a certain simplicity in technique and satisfactory thermal properties (GHAFFARI and HAMEDI-RAD, 2015). The thermal property is also a disadvantage because there is increased heat during polymerization due to the exothermic reaction (SEN et al., 2002).

Recently, bis-acryl-based materials were introduced in dentistry with the purpose of facilitating the preparation of these provisional restorations and improving color stability, handling, strength and esthetics (ULKER et al., 2009). This material has also been used for carrying out the mock-up restorations, which demonstrates the predictability of the final result of the planned esthetic treatment (Da CUNHA et al.,2015; KURBAD, 2015).

Bis- acryl resins are nanofilled compounds that be self-cured, dual cured or by visible light and they are available in a self-mixing system presenting an easier material handling, low exothermic reaction and low polymerization shrinkage (STRASSLER and LOWE, 2011).

Although bis-acryl-based resins have been considered the material of choice for provisional restorations in be case of veneers, their polishing properties still need be addressed, since several polishing procedures are currently available. 
Considering the lack of established polishing techniques for these resins, this study aims to investigate what is the best polishing protocol for different bis-acryl materials with the intention to obtain a smooth surface. 

2 Article 



\section{ARTICLE}

The article presented in this Dissertation was written according to The Journal of Prosthetic Dentistry instructions and guidelines for article submission. 


\title{
INFLUENCE OF THE POLISHING TECHNIQUE ON THE ROUGHNESS AND PROFILE OF BIS-ACRYL-BASED MATERIALS
}

\begin{abstract}
Statement of the problem. The choice of technique and material for making provisional restorations is important. The material must have enough strength to withstand the masticatory loads without suffering deformation or fracture and its surface must have good finishing and polishing to reduce biofilm accumulation.
\end{abstract}

Objective The aim of this study was to investigate what is the best polishing protocol for different bis-acryl materials with the intention to obtain a smooth surface.

Materials and methods. A total of 104 samples were made $(15 \mathrm{~mm}$ long x $5 \mathrm{~mm}$ wide $\mathrm{x} 4 \mathrm{~mm}$ high) and were divided into three study factors: material (Protemp 4, Structur 3, Dencor, Z350XT), polishing (Sof-Lex Pop On and Sof-Lex Spiral discs) and period (initial, postpolishing, post-brushing). Thirteen samples were made per material group, and at each step, a sample was randomly taken for the purpose of submitting to scanning electron microscopy (SEM) analysis, totaling 24 samples to be submitted to this test, and thus, resulting in 80 samples to be brushed, and 10 samples per group for statistical analysis $(n=10)$. In all samples, surface roughness readings $(\mu \mathrm{m})$ were performed at all periods, that is, after they were made, after polishing and after brushing through the rugosimeter (Hommel tester). At the end, the 80 samples were read in a profilometer for analysis of surface wear. The results for the roughness were submitted to ANOVA for three criteria followed by the Tukey's test ( $\alpha=0.05$ ), and for the surface wear test, the results were submitted to ANOVA for two criteria followed by the Tukey`s test $(\alpha=0.05)$.

Results. Protemp 4 bis-acryl showed higher values of surface roughness when polished with Sof-Lex Spiral discs $(0.284 \mu \mathrm{m})$ when compared to Sof-Lex Pop On discs polishing $(0.075$ $\mu \mathrm{m})$. After brushing, there was an increase of surface roughness for both types of polishing. Sof-Lex Spiral discs $(0.375 \mu \mathrm{m})$ and Sof-Lex Pop On discs $(0.359 \mu \mathrm{m})$, but with no significant differences $(p>0.01)$. For the surface wear results, there was no statistical difference between the groups: Protemp 4 bis-acryl resin with Sof-Lex Pop On polishing $(13.95 \mu \mathrm{m})$ and polishing with the Sof-Lex Spiral discs $(14.91 \mu \mathrm{m})$ and the Z350XT composite resin group polished with the two polishing systems - Sof-Lex Pop On and Sof-Lex Spiral $(12.61 \mu \mathrm{m}, 12.70 \mu \mathrm{m}$ respectively).

Structur 3 bis-acryl resin showed lower surface roughness results when polished with Sof-Lex Pop On discs $(0.113 \mu \mathrm{m})$ compared to Sof-Lex Spiral discs $(0.223 \mu \mathrm{m})$. For the surface wear results, there was no difference between the groups of the Structur 3 bis-acryl resin, but the values for both the polished group with Sof-Lex Pop On discs $(15.77 \mu \mathrm{m})$ and the group 
polished with the Sof-Lex discs Spiral $(15.40 \mu \mathrm{m})$ were very close to the values of the group of the Protemp 4 bis-acryl resin and the Z350XT composite resin group, with statistical difference. The two tested bis-acryl resins, the Protemp 4 and Structur 3 in the two polishing systems, showed better surface roughness values $(\mathrm{Ra})$ and lower surface wear values than the Dencor acrylic resin.

Conclusion. By polishing it is possible to improve the surface roughness of the resinous materials, however, the technique, the operator, the materials to be polished and the finishing and polishing system are directly correlated. For the present study, the system that obtained the best results was the Sof-Lex Pop On discs, and the bis-acryl resin that presented the lowest Ra number was the Structur 3 bis-acryl resin. For surface wear, the Structur 3 bis-acryl resin showed higher values compared to the results of the Protemp 4 bis-acryl resin group, which, in turn, showed surface wear values close to that of the Z350 XT composite resin group.

Dencor acrylic resin group showed the highest values of surface roughness (Ra) at all times. After polishing and brushing, the surface roughness presented lower values, when compared to Ra initial values, but this material showed the highest surface wear values $(31.21 \mu \mathrm{m})$.

The resin composite group Z350XT which polishing procedure was Sof-Lex Pop On discs showed lower values $(0.039 \mu \mathrm{m})$. There were no statistically significant differences in surface roughness at all periods and the surface roughness increased after brushing, followed by lower values also for surface wear $(12.61 \mu \mathrm{m})$.

Conclusion. By polishing it is possible to improve the surface roughness of the resinous materials, however, the technique, the operator, the materials to be polished and the finishing and polishing system are directly correlated. For the present study, the system that obtained the best results was the Sof-Lex Pop On discs, and the bis-acryl resin that presented the lowest Ra number was the Structur 3 bis-acryl resin. For surface wear, the Structur 3 bis-acryl resin showed higher values compared to the results of the Protemp 4 bis-acryl resin group, which, in turn, showed surface wear values close to that of the Z350 XT composite resin group.

Key words: Acrylic resin. Bis-acryl. Brushing. Resin Composite. Polishing. Roughness. 


\section{INTRODUCTION}

Dental treatments that demand esthetic and functional restorations with indirect procedures such as ceramic veneers and crowns require the preparation of provisional restorations. However, these provisional restorations can remain in the mouth for longer than expected, until the cementation of the prosthetic restorations. Therefore, provisional materials must present esthetics, strength, and be of easily clinical application. In addition, these materials for temporary restorations must have several colors to allow the reproduction of the tooth structure and provide satisfaction to the patient.

Provisional restoration is an important element that is present during a rehabilitation treatment allowing comfort, occlusion, masticatory function, health and gingival contour, besides allowing aesthetics, function and phonetics and to help the professional to decide if there is adequate occlusal space for the preparation of the tooth for the final restoration. ${ }^{41}$

The choice of the technique and materials used for making provisional restorations are very important. The material must have sufficient thickness and strength to withstand the masticatory loads without suffering deformation or fracture, as well as its surface must be submitted to adequate finishing and polishing procedures to reduce biofilm accumulation and facilitate the cleaning by the patient. ${ }^{36.39 .45}$ Since the biofilm accumulation is harmful to periodontal tissue by generating gingival inflammation, bleeding and gingival recession, ${ }^{46}$ finishing and polishing are used to minimize these problems and improve the clinical performance of materials.$^{2}$

Regarding the cementation of the provisional restorations, there is a consensus on the use of a material that is not irritating to the pulp and that performs the sealing functions, while the provisional restorations remain in the oral cavity. ${ }^{3.15}$ After this period, the periodontal must present itself healthy to provide conditions favorable to the cementing of the definitive piece, 
which often does not occur and thus, makes this process unfeasible, however, currently low intensity laser therapy is showing good results in terms of improving bleeding and reducing inflammation of the periodontal ${ }^{30}$.

Thus, the use of correct finishing and polishing procedures becomes a paramount factor, because they reduce biofilm accumulation, improve the tolerance of the periodontal tissues and increase the resistance of the composite to the impregnation by pigment and wear ${ }^{34.37}$ These procedures make the restoration surface smoothness and more similar to dental enamel. ${ }^{7.25 .40}$ To prevent a significant plaque accumulation, a roughness value of $0.2 \mu \mathrm{m}$ is considered ideal. This value is considered as a parameter and below this value there is lower biofilm accumulation, while above it may cause more accumulation. ${ }^{4}$

Composite resin is one of the materials considered with excellent results of surface roughness when well-made and polished, ${ }^{29}$ but mainly because it maintains surface smoothness in the oral cavity, thus reducing the formation of biofilm. ${ }^{31}$

With the increased demand for esthetics procedures, laminate veneers are more required to improve the harmony of the smile. Therefore, it became essential to use a provisional restorative material that provides such requirements. ${ }^{46.48}$

Chemically activated acrylic resins are the most common used materials for making temporary restorations and their main composition is polymethylmethacrylate. ${ }^{14}$ These resins have some properties that make them good materials to be used until the present day, such as biocompatibility, absence of taste and odor, dimensional stability, good polishing capacity, a certain simplicity in technique and satisfactory thermal properties. ${ }^{13}$ The thermal property is also a disadvantage because there is increased heat during polymerization due to the exothermic reaction. ${ }^{37}$

Recently, bis-acryl-based materials were introduced in dentistry with the purpose of facilitating the preparation of these provisional restorations and improving color stability, 
handling, strength and esthetics. ${ }^{42}$ This material has also been used for carrying out the mockup restorations, which demonstrates the predictability of the final result of the planned esthetic treatment. ${ }^{9.22}$

Bis- acryl resins are nanofilled compounds that be self-cured, dual cured or by visible light and they are available in a self-mixing system presenting an easier material handling, low exothermic reaction and low polymerization shrinkage. ${ }^{39}$

Although bis-acryl-based resins have been considered the material of choice for provisional restorations in be case of veneers, their polishing properties still need be addressed, since several polishing procedures are currently available.

Considering the lack of established polishing techniques for these resins, this study aims to investigate what is the best polishing protocol for different bis-acryl materials with the intention to obtain a smooth surface.

\section{MATERIALS AND METHODS}

\section{Experimental Design}

This study evaluated three factors (materials, polishing techniques and periods during sample handling). Materials were divided in 4 levels: Bis-acryl Protemp 4 (3M ESPE - Dental Products - St. Paul, MN, USA); Bis-acryl Structur 3 (VOCO GmbH - Cuxhaven, Germany); self-curing acrylic resin (Dencor - Articles Dental Classic Ltda. - Campo Limpo Paulista, SP, Brazil); resin composite Filtek Z350 XT (3M ESPE - Dental Products - St. Paul, MN, USA) (Table 1). The polishing techniques were divided in 2 levels: Sof-Lex Spiral discs (3M ESPE St. Paul, MN, USA); Sof-Lex Pop On discs (3M ESPE - St. Paul, MN, USA). Periods during sample handling was divided in 3 levels, according to the step during sample's preparation: 
initial, after polishing and after brushing (Table 2). Control groups were resin composite and acrylic resin due to the well-known polishing procedures already being extensively described.

The response variables were $\mathrm{Ra}(\mu \mathrm{m})$ and wear $(\mu \mathrm{m})$ obtained through a rugosimeter (Hommel tester T1000 basic - Hommelwerke GmbH - Schwenningen, Germany).

Table 1. Material used in the present study

MATERIAL

Bis-acryl resin Protemp 4

(3M ESPE- Dental Products - St. Paul MN USA

COMPOSITION

2,2 ;

[(1- Application- $40 \mathrm{~s}$; Setting time methylethylidene) bis (4.1- in oral cavity- $40 \mathrm{~s}-1 \mathrm{~min} 40 \mathrm{~s}$; phenyleneoxy)] bis-. diacetate; Removal- 1 min $40 \mathrm{~s}-2$ min Silane-treated silica; Acid $50 \mathrm{~s}$; Final setting time- 5 min; benzyl-phenyl-barbituric acid; Finishing- 5min

Tert-butyl 3.5.5-trimethyl

peroxihexanoato

Bis-acryl resin Structur 3 BisGMA/UDMA/TEDMA; Application- 0 s; Setting time (VOCO GmbH - Bis acetylated BPA; in oral cavity- $30 \mathrm{~s}$; RemovalCuxhaven - Germany) diglicidileter; Silica; BHT; 1 min 4; Final setting time- 1 pigments $\quad \min 30 \mathrm{~s}$; Finishing- $4 \mathrm{~min}$

Acrylic resin Dencor Powder: Copolymer Methyl $3 \mathrm{~cm}^{3}(\mathrm{ml})$ of powder to $1 \mathrm{~cm}^{3}$

(Dencor-Articles Dental Ethyl Methacrylate; Organic (ml) of liquid (3: 1). Mix until Classic Ltda -Field Limpo pigments; Peroxide. Liquid: a dough is homogeneous (it is Paulista-SP-Brazil) Methyl Methacrylate recommended to use the Monomer; DMT; Cross-Link. spatula for handling). Wait for a plastic phase for application

Resin composite Filtek Silanized ceramic treated; After insertion of 2-mm-thick Z350 XT (3M ESPE- Bisphenol A diglycidyl ether portions light-cure for 20 Dental Products - St. Paul dimethacrylate BIS-GMA seconds MN - USA (bisphenol glycidyl methacrylate); sílica treated with silane - zirconium oxide treated with silane; diurethane dimethacrylate; polyethylene glycol dimethacrylate; TEGDMA (triethylene glycol dimethacrylate); 2.6-di-tertbutyl-p-cresol (BHT) 
Table 2. Groups according to polishing techniques and material

\begin{tabular}{lll} 
Groups & Material & \multicolumn{1}{c}{ Polishing } \\
\hline Protemp 4 & Bis-acryl resin & Sof-Lex Pop-On \\
& & Sof-Lex Spiral \\
\hline Structur 3 & Bis-acryl resin & Sof-Lex Pop-On \\
\cline { 2 - 2 } & & Sof-Lex Spiral \\
\hline Dencor & Acrylic Resin & Sof-Lex Pop-On \\
\cline { 2 - 2 } & & Sof-Lex Spiral \\
\hline Z350XT & Resin Composite & Sof-Lex Pop-On \\
\cline { 2 - 2 } & & Sof-Lex Spiral
\end{tabular}

\section{Samples Preparation}

One hundred and four samples were prepared (thirteen samples for each group). For each completed step (i.e. moment during sample preparation), one sample of each group was randomly selected to for Scanning Electron Microscopy (SEM, JSM - T220A - JOEL Ltda., Tokyo, Japan), resulting in 10 sample in each group $(n=10)$. Bar-shaped samples of 15-mmlong, 5-mm-wide, and 4-mm-deep were prepared with the mold described on Figure 1.

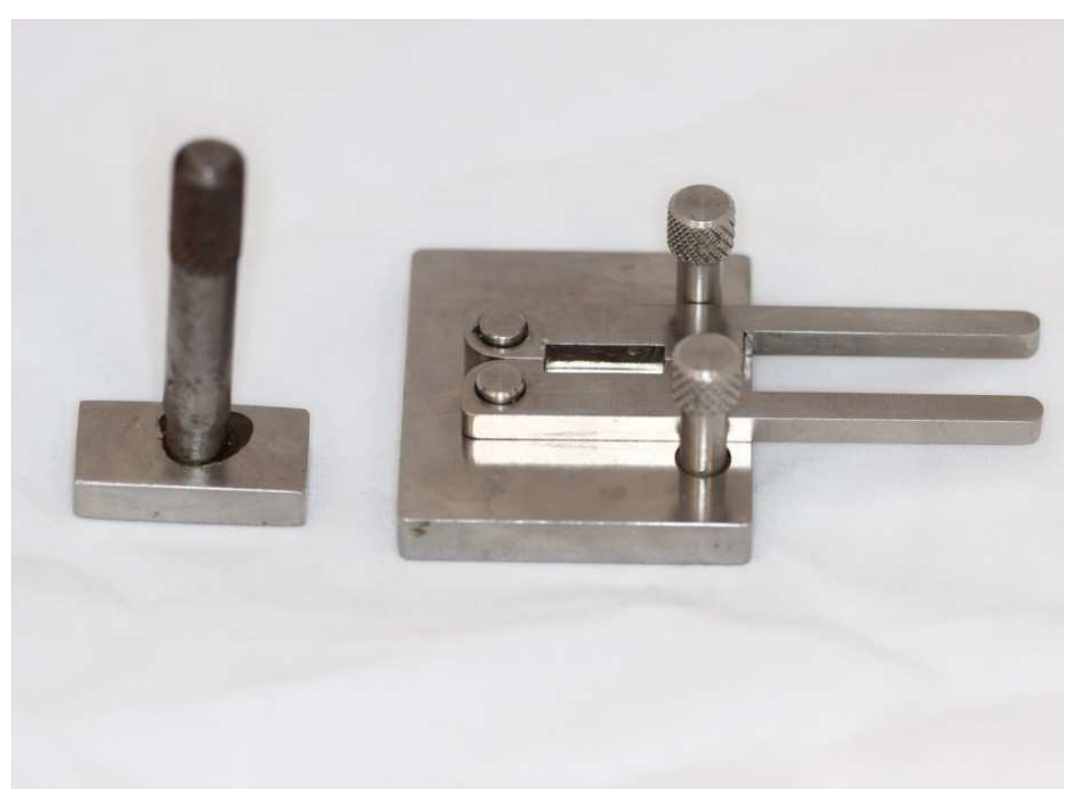

Figure 1. Metallic mold used for samples preparation. 


\section{Bis-acryl samples}

The bis-acryl resin was inserted in the steel mold in a single increment with the aid of the dispenser provided. After insertion into the mold, the material was pressed with an addition silicone handled according to the manufacturer, being that, for each sample, a matrix of addition silicone was made, discarding it after use (Adsil Putty Soft - VIGODENT S/A Ind. and Com. Rio de Janeiro, RJ, Brazil) and the metallic part of the mold described in Figure 1 with a pressure of $500 \mathrm{~g}$ to obtain a flat surface. (Figures $2 ; 2 \mathrm{~A} ; 2 \mathrm{~B}$ ). The material remained untouched for the curing time recommended by the manufacturer. After waiting the curing time, ethyl alcohol was applied for removing the inhibition layer (Figures 2C; 2D). Then, the metallic part was removed to free samples from the metallic mold by removing the side screws (Figure 2E)

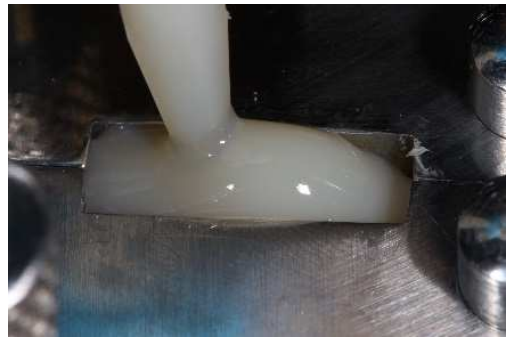

Figure 2

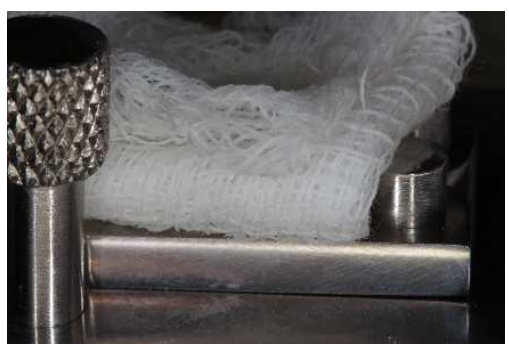

Figure 2C

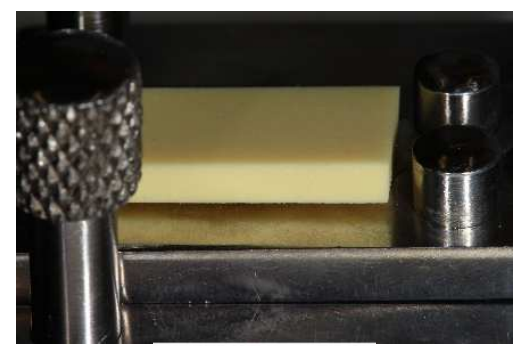

Figure 2A

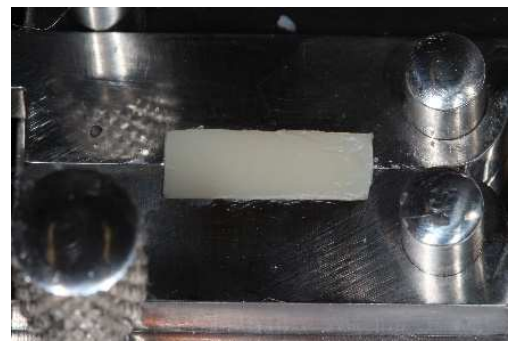

Figure 2D

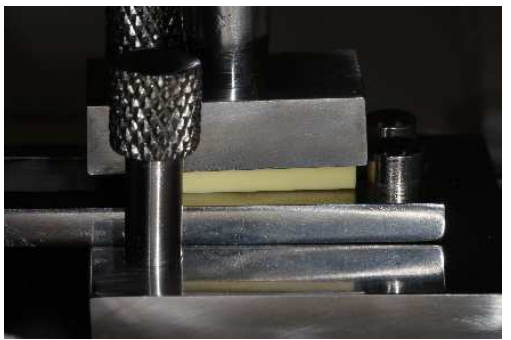

Figure 2B

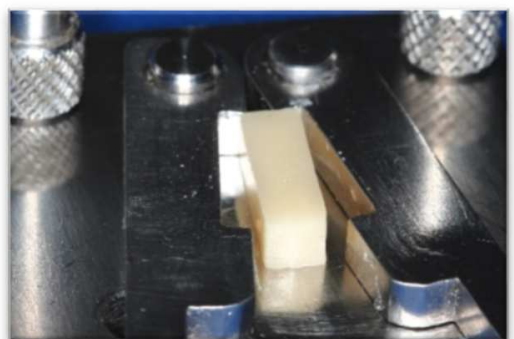

Figure 2E

Fig 2, 2A, 2B, 2C, 2D 2E - preparation sequence of the bis-acryl resin samples and removal of the metallic matrix

\section{Acrylic resin samples}

The acrylic resin was handled according to the manufacturer $3: 1$ by volume and set in a single increment with a spatula in the metal matrix and with vibration apparatus that does not 
have the occurrence of bubbles, so that the acrylic resin did not stick to the metallic base of the stainless steel matrix that served as the sample height parameter, we brush the monomer in the part where it would be in contact with the acrylic resin, serving as an insulator between the metallic base of the stainless steel matrix and the acrylic resin being placed.

The samples were fixed in sticky wax Kota (Kota Ind. and Com. Ltda., São Paulo, SP, Brazil), with the aid of an insertion tool (Duflex) and a lamp (JON) in the center of an acrylic plate (30 $\mathrm{mm}$ diameter and $8 \mathrm{~mm}$ in thickness) in order to perform surface roughness and polishing.

\section{Resin composite samples}

The insertion of the resin composite was executed by incremental technique, with 2mm-thick increments, in a total of four increments. Each increment was inserted at the mold and light cured, using a LED device (Curing Light - Dabi Atlante - Ribeirão Preto, SP, Brazil) DB685 model - frequency 50 / 60Hz. and 1.5VA Power, with $935 \mathrm{~mW} / \mathrm{cm}^{2}$, for $20 \mathrm{~seconds}$ with the tip of the device positioned as close as possible of the resin composite. The irradiance was measured with a radiometer ECEL RD-7 (ECEL Ind. and Com. Ltda., Ribeirão Preto, SP, Brazil). Since samples were 15-mm-long and the tip of the LED device has a diameter of $8 \mathrm{~mm}$, each increment was light cured twice (one at each part of the length mold).

The final increment was pressed with a polyester strip (TDV Dental LTDA - Pomerode, $\mathrm{SC}$, Brazil) and the metallic part of the mold described in Figure 1 with a pressure of $500 \mathrm{~g}$ for $30 \mathrm{~s}$ to obtain a flat surface. After this time, the metallic part was removed and the resin composite was light cured through the polyester strip and samples were removed from the metallic mold.

Samples were then fixed on an acrylic disk and had their surfaces standardized in a polishing machine (Arapol 2V - Arotec, Cotia, SP), using sandpapers with different granulations: 320, 400, 600 and 1200 (Extec Corp.) at low speed and standard weight of 172g 
for 2 minutes under deionized water irrigation. Finally, resin composite samples were finalized with felt disc (Extec Corp.) moistened with $1 \mu \mathrm{m}$ diamond suspension for 4 minutes at high speed with the same weight. This procedure was performed to standardize the initial surface roughness of the composite resin groups since the digital pressure exerted under the polyester strip could interfere and alter the results of some samples from the group.

\section{Cleaning of samples}

After preparation, samples were immersed in deionized distilled water and submitted to ultrasonic vibration (T7 Thorton, Unique Ind. and Com. of Electronic Products Ltda., São Paulo, SP) for 5 minutes. After this procedure, the samples were dried with absorbent paper to read the surface roughness.

\section{Initial surface roughness}

After preparation, all samples were submitted to the first evaluation surface roughness. Three readings of the surface roughness were made with a rugosimeter (Hommel tester T1000 basic) and the arithmetic mean was obtained ( $\mathrm{Ra})$.

The parameter that is used to obtain the surface roughness is the arithmetic roughness (Ra) determined by the average (in $\mu \mathrm{m}$ ) of 3 readings. This parameter expresses the arithmetical average value of all absolute distances of the roughness profile $(\mathrm{R})$ from the centerline within the measuring length Lm. The following parameters were used:

$$
\begin{aligned}
\text { Minimum } \mathrm{T} & =0.01 \mathrm{~mm} \\
\text { Maximum } \mathrm{T} & =0.8 \mathrm{~mm} \\
\mathrm{Lt} & =10 \mathrm{~mm} \\
\mathrm{Lc} & =0.25 \mathrm{~mm} \text { (cutt-off) } \\
\mathrm{Lm} & =4.5 \mathrm{~mm}
\end{aligned}
$$


Where:

$$
\begin{aligned}
& \mathrm{T}=\text { tolerance (extreme values to be considered in readings) } \\
& \mathrm{Lm}=\text { measuring limit (considered extension of reading) } \\
& \mathrm{Lt}=\text { trail limit (actual extent covered by the measuring probe tip) } \\
& \mathrm{Lc}=\text { cut-off (filtering to minimize the surface ripple interference). }
\end{aligned}
$$

All the samples were immersed in distilled water solution for 24 hours at $37^{\circ} \mathrm{C}$.

\section{Polishing and finishing}

Each material was divided in two polishing:

1. Sof-Lex Pop On discs: polishing was conducted by positioning the samples on a scale (Electronic Kitchen scale - SF - 400), with controlled weight varying between 150 and 300 grs using a low speed hand piece (Dabi Atlante - N270 at $10.000 \mathrm{rpm}$ ) for 20 seconds for each grain (one-way movements). The discs were discarded after use. The four available granulations provided by the manufacturer (coarse, medium, fine and extra-fine) were used. Between each exchange sandpaper the samples were be cleaned in ultrasound device T7 Thorton (Unique Ind. and Com. of Electronic Products Ltda., São Paulo, SP) with frequency of $40 \mathrm{kHz}$ for 5 minutes.

2. Sof-Lex Spiral discs: A finishing and polishing system containing 2 colordifferentiated granulations - beige (thicker granulation) for finishing, and white (thinner granulation) for polishing, according to the manufacturer, all the samples were polished at low speed, for 20 seconds. on a scale (Electronic Kitchen scale SF - 400), with controlled weight and varying between 150 and 300 grs. All the samples were polished at low speed, for 20 seconds, following the sequence provided by the manufacturer. In each exchange rubbers the samples are washed in 
an ultrasonic tank for 5 minutes with deionized distilled water, and for each new step, the samples are dried on paper towels.

The reading of surface roughness after polishing was performed following the same method described above.

\section{Abrasion procedure 28.29 .32 .40}

Previously to the abrasion procedure, half of the sample was protected with an insulation tape. The brushing simulation machine (MN São Carlos, SP, Brazil), which has a motor, also has 10 arms to fix the heads of dental brushes Essential Clean (Colgate Palmolive Ind. Ltda., São Bernardo do Campo, SP, Brazil), ensuring their parallel alignment to the base, which is made of stainless steel, and has ten independent devices for the positioning of the samples. This machine contains a temperature sensor that allows for brushing at a temperature of $37 \pm 1^{\circ} \mathrm{C}$, through precise monitoring and without external interference. The movements of the brushing were adjusted to an excursion amplitude of $20 \mathrm{~mm}$ being this amplitude compatible with the size of the samples. With $300 \mathrm{~g}$ load, the cycles were set at a rate of 5.5 cycles per second, and the calibrated equipment frequently injected $0.4 \mathrm{ml}$ of slurry into each test body every 120 seconds. The solution (slurry) was prepared at the time of use, in order to preserve its characteristics, using a Colgate Triple Action dentifrice (Colgate Palmolive Ind. Ltda., São Bernardo do Campo, SP, Brazil) and distilled water at a ratio of 1:2 by weight where it will be weighed and diluted within a Becker with distilled water. The samples were randomly placed by drawing among the 88 samples prepared and all 88 samples were brushed until 50.000 cycles were completed each. At the end, the samples were cleaned in running water with the aid of a clinical clamp, after being removed from the metal matrix of the machine, and then washed in an ultrasonic tank during 5 minutes in order to remove the abrasive particles from the toothpaste, the surfaces of the samples, and dried on absorbent paper. 


\section{Determination of surface roughness after brushing}

The insulation tape was removed from the sample with a scalpel blade and the surface roughness reading was performed following the same method previously described. Three readings were performed in each sample, only on the brushed side.

\section{Determination of surface wear}

The samples were positioned for the surface wear reading so that the reading was made perpendicular to the direction of movement of the simulated brush in the Hommel Tester T1000 basic (Hommelwerke GmbH - Schwenninguem, Germany) was used as profilometer, where calibration was performed through the spherical probe tip that runs through the surface and is coupled to a unit that processes the information quantitatively. The parameters used were:

$$
\begin{aligned}
& \mathrm{T} \text { minimum }=8 \mu \mathrm{m} \\
& \mathrm{T} \text { maximum }=40 \mu \mathrm{m} \\
& \mathrm{Lt}=5 \mathrm{~mm} \\
& \mathrm{Lc}=0.25 \mathrm{~mm} \text { (cut-off) } \\
& \mathrm{Lm}=4.5 \mathrm{~mm}
\end{aligned}
$$

Where:

$$
\begin{aligned}
& \mathrm{T}=\text { tolerance (extreme values to be considered in readings) } \\
& \mathrm{Lm}=\text { measuring limit (considered extension of reading) } \\
& \mathrm{Lt}=\text { trail limit (actual extent covered by the measuring probe tip) } \\
& \mathrm{Lc}=\text { cut-off (filtering to minimize the surface ripple interference). }
\end{aligned}
$$

The equipment is connected to a microcomputer that processes all the necessary information. With the aid of the equipment's software (Turbo Datawin-NT, version 1.34, copyright $\lceil 2001)$ the real profiles of the tested surfaces were obtained to quantify the wear. The profile obtained by the rugosimeter, runs through the surface of the samples passing through the 
half that were suffer the abrasiveness (brushed side) and the half that will not suffer abrasiveness (control side). The profilometer measures the distance in micrometers $(\mu \mathrm{m})$. Three readings were performed on each sample.

\section{Scanning Electron Microscopy (SEM)}

After surface wear evaluations, one sample from each group was randomly selected to be submitted to SEM for illustrative purposes. The samples were kept at room temperature for 12 hours, after which they were mounted on aluminum stubs, fixed with colorless nail polish (Risque - Niasi - Taboão da Serra, SP, Brazil) and metallized with gold-palladium on a metallizer (DentronVacuum - Desk IV Moostestonn / NJ, USA), prior to SEM observation (JSM-T220A - JOEL Ltda., Tokyo, Japan), with 200x magnification.

\section{Statistical analyses}

For roughness, data were submitted to three-way Anova, considering resin-based material, polishing techniques and moment according to the step during sample's preparation as independent variables. For surface wear data were submitted to two-way Anova, considering resin-based material and polishing techniques as independent variables. Multiple comparisons were performed by the Tukey test. A global level of significance of 5\% was used.

\section{RESULTS}

Mean values and standard deviations for roughness (initial, after polishing and after brushing) and wear (after brushing) are shown on Table 3. 


\section{Surface Roughness}

For roughness, there were significant differences between resin-based material $(\mathrm{p}<$ 0.0001), polishing techniques $(\mathrm{p}=0.0009)$ and moment according to the step during sample's preparation $(\mathrm{p}<0.0001)$. Interactions between resin composites and polishing techniques $(\mathrm{p}=$ 0.000874); resin-based material and time $(\mathrm{p}<0.0001)$; polishing and time $(\mathrm{p}<0.0001)$; and resin-based material, polishing and time $(\mathrm{p}=0.0065)$ were also found to be significant.

Table 3 - Mean and standard deviation of Polishing, Roughness and Wear of the different tested materials

\begin{tabular}{|c|c|c|c|c|}
\hline Material & Polishing & Periods & Roughness & Wear \\
\hline \multirow{6}{*}{ Protemp 4} & \multirow{3}{*}{$\begin{array}{l}\text { Sof-Lex Pop } \\
\text { On }\end{array}$} & Initial & $0.388(0.044)^{\mathrm{f.g}}$ & \multirow[t]{3}{*}{$13.95(1.24)^{\mathrm{A} . \mathrm{B}}$} \\
\hline & & Polishing & $0.075(0.008)^{\text {a.b.c }}$ & \\
\hline & & Brushing & $0.360(0.019)^{\mathrm{f.g}}$ & \\
\hline & \multirow{3}{*}{$\begin{array}{c}\text { Sof-Lex } \\
\text { Spiral }\end{array}$} & Initial & $0.422(0.051)^{\mathrm{g}}$ & \multirow{3}{*}{$14.91(2.26)^{\mathrm{A} . \mathrm{B}}$} \\
\hline & & Polishing & $0.284(0.055)^{\mathrm{e} . \mathrm{f}}$ & \\
\hline & & Brushing & $0.375(0.039)^{\mathrm{fg}}$ & \\
\hline \multirow{6}{*}{ Structur 3} & \multirow{3}{*}{$\begin{array}{l}\text { Sof-Lex Pop } \\
\text { On }\end{array}$} & Initial & $0.155(0.020)^{\mathrm{c} . \mathrm{d}}$ & \multirow{3}{*}{$15.77(1.32)^{\mathrm{C}}$} \\
\hline & & Polishing & $0.113(0.040)^{\text {a.b.c.d }}$ & \\
\hline & & Brushing & $0.340(0.036)^{\text {e.f.g }}$ & \\
\hline & \multirow{3}{*}{$\begin{array}{c}\text { Sof-Lex } \\
\text { Spiral }\end{array}$} & Initial & $0.154(0.022)^{\mathrm{c.d}}$ & \multirow{3}{*}{$15.40(2.05)^{\mathrm{C}}$} \\
\hline & & Polishing & $0.223(0.055)^{\text {d.e }}$ & \\
\hline & & Brushing & $0.312(0.057)^{\text {e.f.g }}$ & \\
\hline \multirow{6}{*}{ Dencor } & \multirow{3}{*}{$\begin{array}{c}\text { Sof-Lex Pop } \\
\text { On }\end{array}$} & Initial & $3.510(0.273)^{\mathrm{i}}$ & \multirow{3}{*}{$31.21(3.66)^{\mathrm{D}}$} \\
\hline & & Polishing & $0.148(0.034)^{\mathrm{c.d}}$ & \\
\hline & & Brushing & $0.601(0.091)^{\mathrm{h}}$ & \\
\hline & \multirow{3}{*}{$\begin{array}{c}\text { Sof-Lex } \\
\text { Spiral }\end{array}$} & Initial & $3.553(0.148)^{\mathrm{i}}$ & \multirow{3}{*}{$29.80(4.30)^{\mathrm{D}}$} \\
\hline & & Polishing & $0.232(0.040)^{\text {d.e }}$ & \\
\hline & & Brushing & $0.406(0.058)^{f . g}$ & \\
\hline \multirow{6}{*}{ Z350XT } & \multirow{3}{*}{$\begin{array}{c}\text { Sof-Lex Pop } \\
\text { On }\end{array}$} & Initial & $0.019(0.039)^{\mathrm{a}}$ & \multirow{3}{*}{$12.61(1.24)^{\mathrm{A}}$} \\
\hline & & Polishing & $0.039(0.005)^{a . b . c}$ & \\
\hline & & Brushing & $0.136(0.027)^{\text {a.b.c.d }}$ & \\
\hline & \multirow{3}{*}{$\begin{array}{c}\text { Sof-Lex } \\
\text { Spiral }\end{array}$} & Initial & $0.020(0.006)^{a . b}$ & \multirow{3}{*}{$12.70(1.64)^{\mathrm{A}}$} \\
\hline & & Polishing & $0.130(0.041)^{\text {a.b.c.d }}$ & \\
\hline & & Brushing & $0.141(0.033)^{\text {b.c.d }}$ & \\
\hline
\end{tabular}

Similar lowercase and uppercase superscript letters means no significant differences $(\mathbf{p}<0.05)$ 

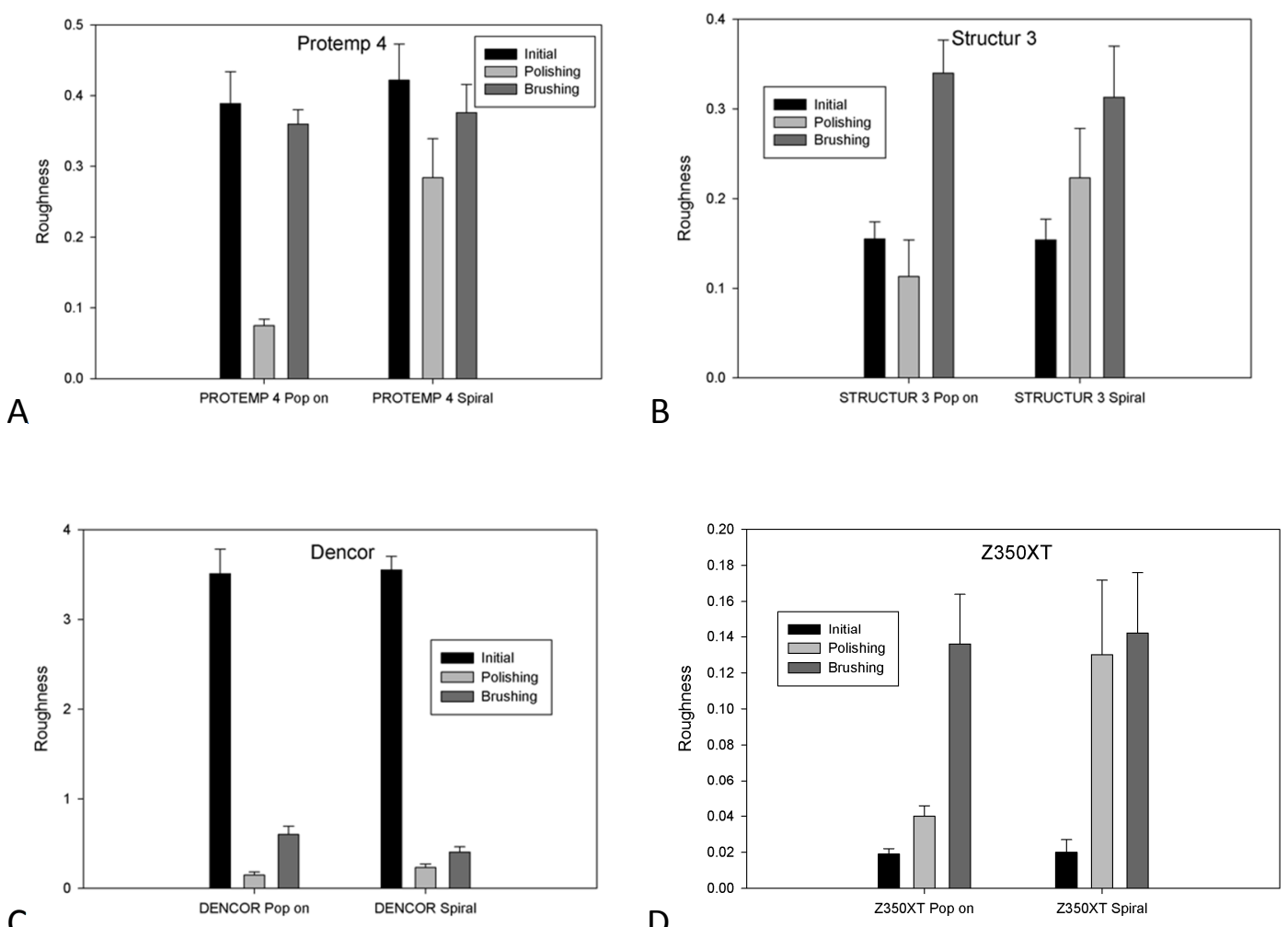

Figure 3. Graphics representing the $\mathrm{Ra}$ values in all times for the different tested materials. Being the group Protemp 4 (A); Structur 3 (B); Dencor (C); Filtek Z350XT (D); Note that the scale at the $y$-axis changes according to the material.

Higher initial roughness was found for the acrylic resin and lower values were found for the resin composite. The two bis-acrylic resins showed intermediate values.

For the Protemp 4 group polished with Sof-Lex Pop On, there was statistical difference between the initial $\mathrm{Ra}(0.388 \mu \mathrm{m})$ and after polishing $(0.075 \mu \mathrm{m})$. After brushing the $\mathrm{Ra}$ increased, presenting significant statistical difference when compared to the polishing $(\mathrm{p}<$ 0.05). Polishing with Sof-Lex Spiral showed a significant statistical difference between the initial $\mathrm{Ra}(0.422 \mu \mathrm{m})$ and $\mathrm{Ra}$ after polishing $(0.284 \mu \mathrm{m})$. After brushing, Ra values increased $(0.375 \mu \mathrm{m})$, presenting a statistically significant difference when compared to the polishing, but did not present statistical significant difference when compared to the initial $\mathrm{Ra}$ value $(\mathrm{p}>$ 0.001). The polishing with Sof-Lex Pop On resulted in smaller roughness than the Spiral disc $(\mathrm{p}<0.05)$. 
In the Structur 3 group there was no statistically significant difference between the initial $\mathrm{Ra}(0.154 \mu \mathrm{m})$ and Ra post-polishing $(0.113 \mu \mathrm{m})$ when polished with Sof-Lex Pop On discs. After brushing, Ra values increased $(0.340 \mu \mathrm{m})$ and there was difference when compared to initial $\operatorname{Ra}(\mathrm{p}>0.05)$. For the polished group with Sof-Lex Spiral discs, at the initial Ra and post-polishing there was no statistical difference $(\mathrm{p}>0.05)$. Only after brushing $(0.312 \mu \mathrm{m})$ there was a statistically significant difference when compared to initial Ra values $(\mathrm{p}<0.05)$. Comparing the two bis-acrylic resins between each other, higher initial roughness was observed for Protemp $4(\mathrm{p}<0.05)$

The Sof-Lex Pop On discs showed lower Ra values for the two bis-acryl groups (Structur 3 and Protemp 4), compared to the Sof-Lex Spiral discs. However, there was statistical difference only between the polishing procedures in the Protemp 4 group $(\mathrm{p}<0.05)$.

After brushing, Protemp 4, for the two types of polishing, the Ra values had no statistical difference when compared to the initial $\mathrm{Ra}(\mathrm{p}>0.05)$.

For Dencor acrylic resin polished with Sof-Lex Pop On discs, there was a statistically significant difference $(\mathrm{p}<0.05)$ in Ra at all times: initial $(3.510 \mu \mathrm{m})$, after polishing $(0.148 \mu \mathrm{m})$ and after brushing $(0.600 \mu \mathrm{m})$. For Sof-Lex Spiral group there were statistically significant differences $(\mathrm{p}<0.05)$ in the Ra values at all times: initial $\mathrm{Ra}(3.553 \mu \mathrm{m}) \mathrm{Ra}$ after polishing $(0.232 \mu \mathrm{m})$ and Ra after brushing $(0.406 \mu \mathrm{m})$.

Z350 XT group did not show statistically significant difference at all times for the two polishing systems $(\mathrm{p}>0.05)$. 


\section{Surface Wear}

For surface wear, there were significant differences between resin-based material $(\mathrm{p}<$ $0.0001)$, but no differences for polishing techniques $(\mathrm{p}=0.74)$. The interaction was not significant $(\mathrm{p}=0.5)$.

\section{Scanning Electronic Microscopy (SEM)}

The following SEM images show the difference among the sample in three steps: initial roughness surface, after polishing and after brushing procedures.

For the Protemp 4 bis-acryl group, Sof-Lex Pop On discs showed better polishing results when compared to Sof-Lex Pop Spiral (Figures 4 and 5).

Structur 3 (bis-acryl resin) presented grooves on initial surface e roughness that became less evident after both types of polishing procedures, followed by a smoother surface after brushing (Figures 6 and 7).

For the acrylic resin group, with Sof-Lex Pop On polishing discs (Figure 8) it is possible to observe that there were grooves on the surface that were removed after brushing. While on the Sof-Lex Spiral discs' group (Figure 9) the grooves appeared after brushing.

The resin composite group (Figures 10 and 11) showed grooves all over the surface after polishing for both procedures types (Sof-Lex Pop On and Sof-Lex Spiral) and the roughness is more evident after brushing for this material. 


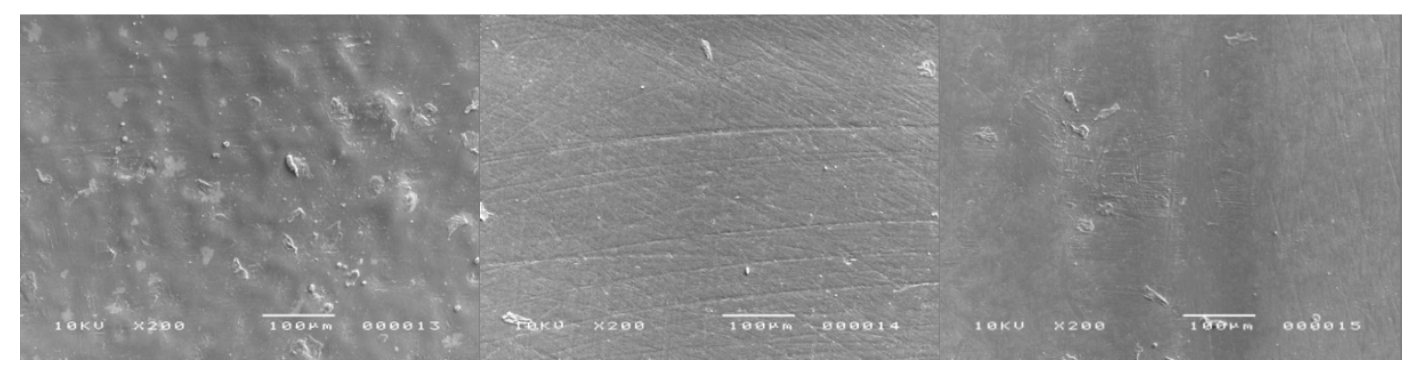

A

B

C

Figure 4. Bis-acryl resin (Protemp 4) - 200x magnification. A) Initial Roughness Surface; B) Polishing with Sof-Lex Pop On discs; C) Brushing procedure.

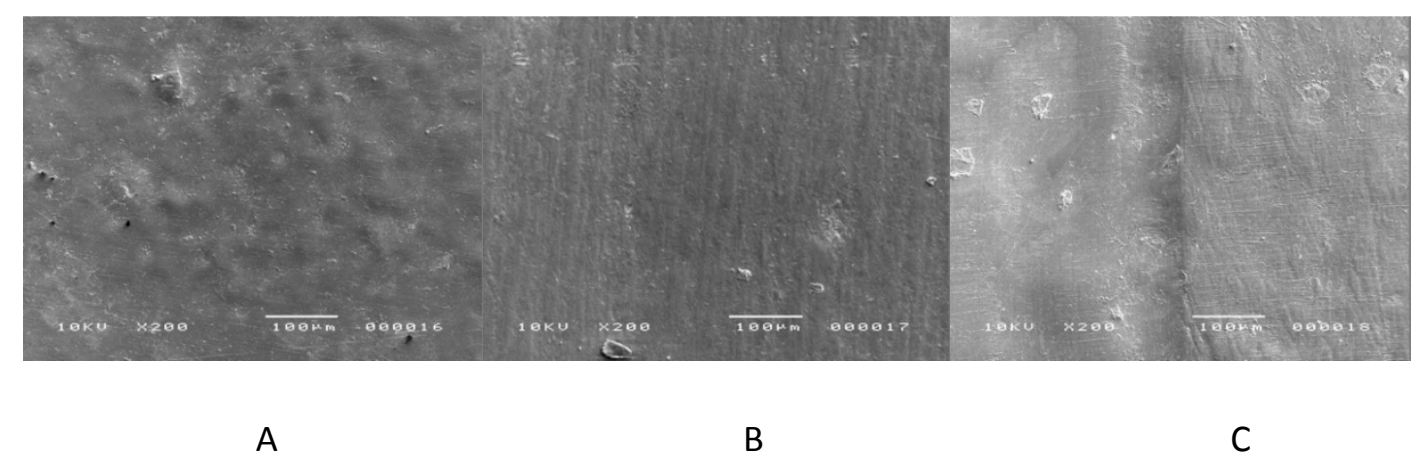

Figure 5. Bis-acryl resin (Protemp 4) - 200x magnification. A) Initial Roughness Surface; B) Polishing with Sof-Lex Spiral discs; C) Brushing procedure.

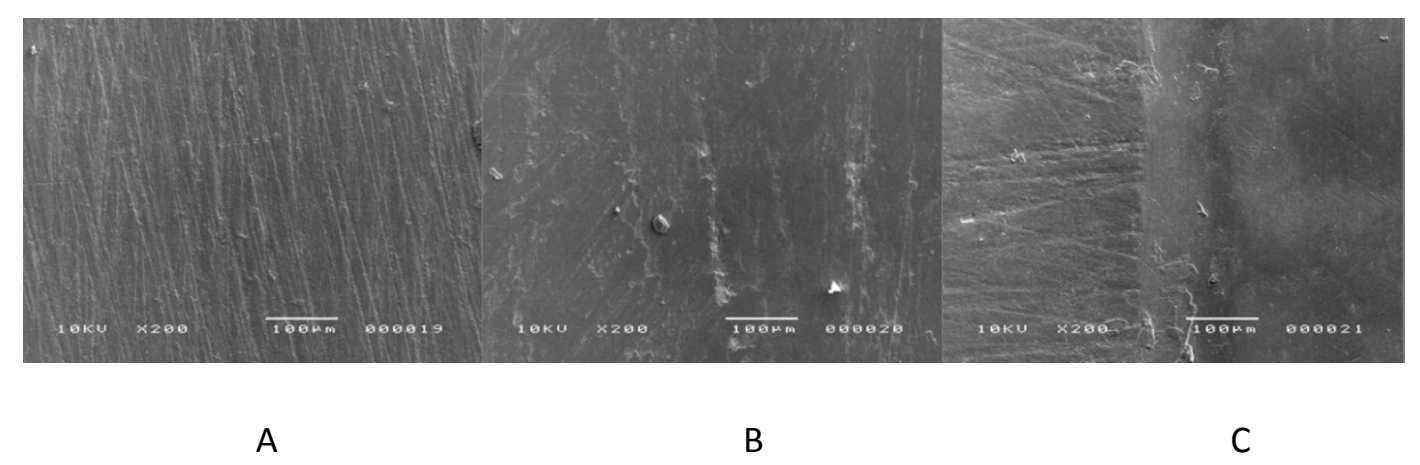

Figure 6. Bis-acryl resin (Structur 3) - 200x magnification. A) Initial Roughness Surface; B) Polishing with Sof- Lex Pop On discs; C) Brushing procedure. 


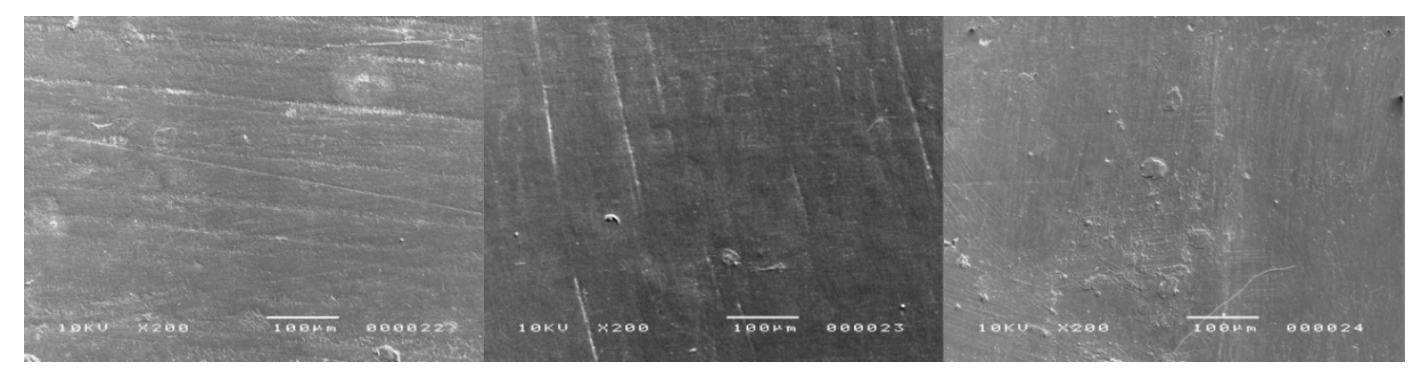

A

B

C

Figure 7. Bis-acryl resin (Structur 3) - 200x magnification. A) Initial Roughness Surface; B) Polishing with Sof- Lex Spiral discs; C) Brushing procedure.

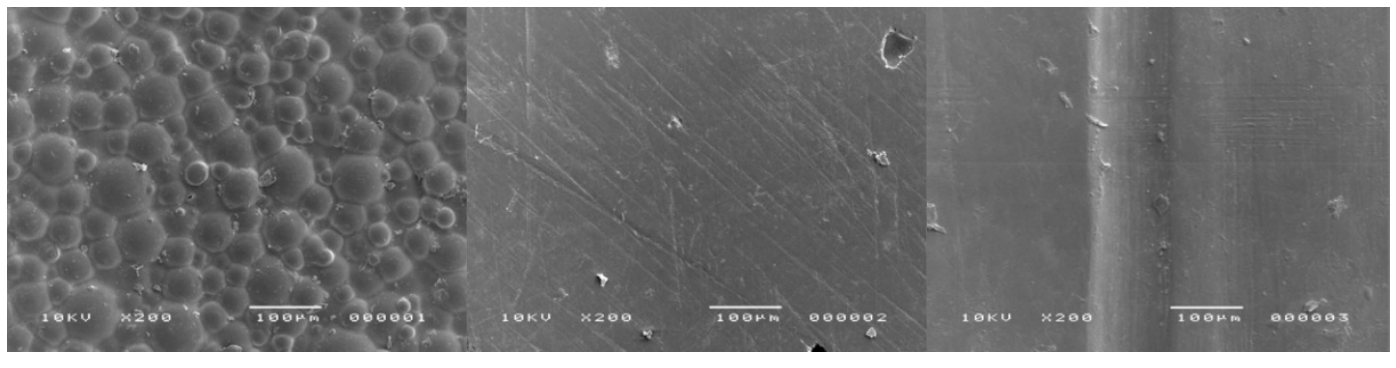

A

B

C

Figure 8. Acrylic resin group (Dencor) - 200x magnification. A) Initial Roughness Surface; B) Polishing with Sof- Lex Pop On discs; C) Brushing procedure.

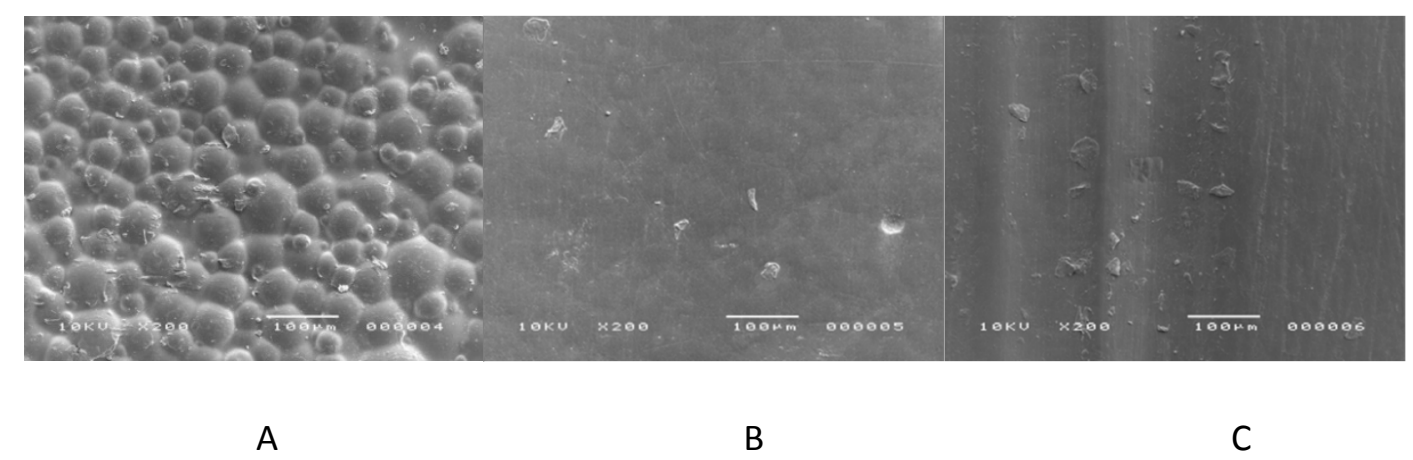

Figure 9. Acrylic resin group (Dencor) - 200x magnification. A) Initial Roughness Surface; B) Polishing with Sof- Lex Spiral discs; C) Brushing procedure. 


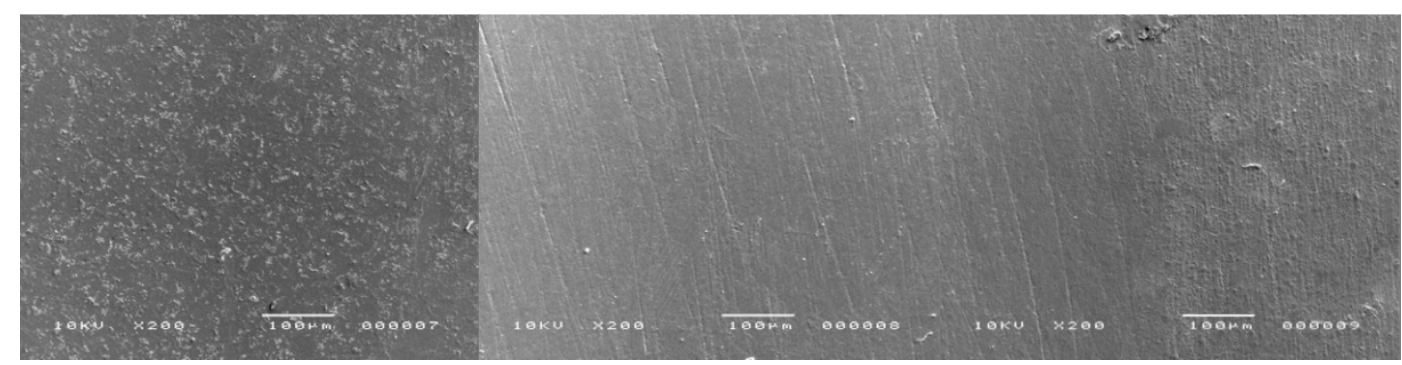

A

B

C

Figure 10. Composite resin (Filtek Z350XT) - 200x magnification. A) Initial Roughness Surface; B) Polishing with Sof-Lex Pop On discs; C) Brushing procedure.

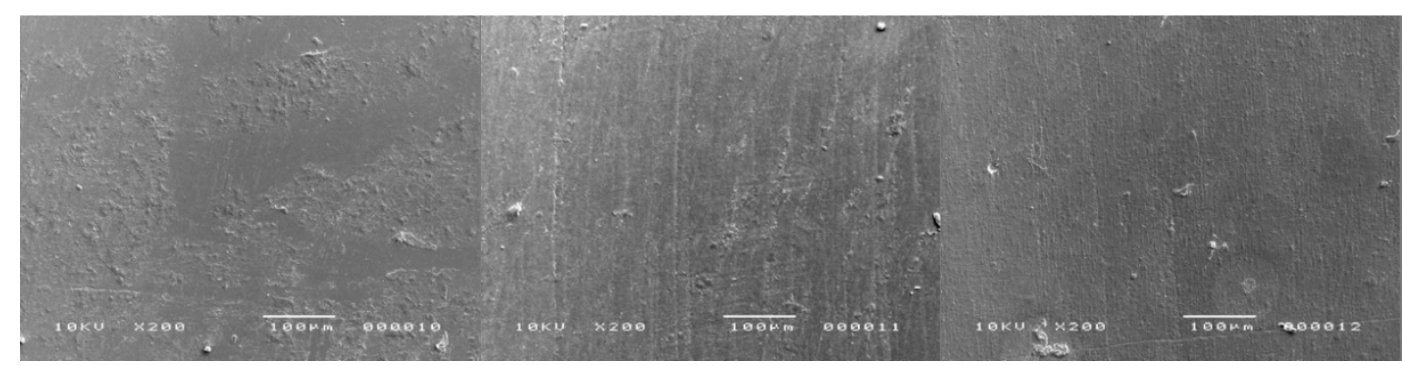

Figure 11. Composite resin (Filtek Z350XT) - 200x magnification. A) Initial Roughness Surface; B) Polishing with Sof-Lex Spiral discs; C) Brushing procedure.

\section{DISCUSSION}

The available trademarks used in this study were: two bis-acryl resins (Protemp 4 and Structur 3), a chemically activated acrylic resin (Dencor) and a nanofilled resin composite (Filtek Z350 XT). As they are different materials, with different compositions, the surface roughness values at all times between the materials would be different, but the purpose of this study was to evaluate a finishing and polishing system that offers better surface roughness results for the tested bis-acryl resins.

Although provided by the same manufacturer, the finishing and polishing systems used in this study were consisted of discs (Sof-Lex Pop On) of four granulations or discs (Sof-Lex 
Spiral) of two granulations. As observed in the present study, both systems were able to to reduce the surface roughness. However, the Sof-Lex Pop On showed a better overall behavior. Each system depends on its abrasive power, ${ }^{8.19 .36 .45 .46 .47}$ they are basically divided into the following categories: diamond and multilayer tips, abrasive rubbers, silicon tips, discs and abrasive strips, felt disks, silicon carbide brush and diamond pastes.

Finishing and polishing procedures in restorations with acrylic resins, resin composites and bis-acryl is important to the clinical longevity of the restoration, indicating that it is satisfactory when it results in a surface that presents esthetics, smoothness, brightness and preservation of periodontal tissues. ${ }^{4 \cdot 6 \cdot 10.21 .25}$ However, the surface roughness is also correlated with the biofilm accumulation, extrinsic pigmentation, abrasiveness and material wear. ${ }^{1.4 .23 .24}$ The surface roughness of a material that does not promote periodontal disease due to biofilm accumulation ideally would be equal to or less than $0.2 \mu \mathrm{m} .{ }^{4}$

In the present study, the bis-acryl resin Protemp 4 presented Ra values higher than $0.2 \mu \mathrm{m}$. This value may suggest that the material is more vulnerable to biofilm accumulation, ${ }^{4}$ which is in agreement with the literature that presented even higher values of Ra. ${ }^{20}$ After polishing with Sof-Lex Pop On discs and Sof-Lex Spiral discs, the Ra decreased considerably, although after brushing it did not show significant statistical difference, despite showing increased values.

For this study, bis-acryl resin Structur 3 group showed that the initial Ra values were equal to or less than $0.2 \mu \mathrm{m}$, which may suggest a lower biofilm accumulation and periodontal consequences, ${ }^{4}$ although there was an increase in Ra value for the group polished with SofLex Spiral discs, without statistically significant difference when compared to the other polishing system tested the Sof-Lex discs and the superficial wear after brushing for both groups.

However, among the groups of the bis-acryl resins tested, Structur 3 obtained the best 
results regarding surface roughness, but suffered more wear when submitted to the abrasion procedure when compared to Protemp 4.

The polishing of the samples of this study, was performed 24 hours after the preparation because some studies have shown that there is a better marginal seal if the polishing is delayed for this time, except the bis-acryl group in which the polishing procedure was realized after the setting time according to the manufacture instructions. Other authors reported that immediate finishing and polishing might result in plastic deformation of the composite resin. ${ }^{11.21 .25}$

The control group Filtek Z350XT resin composite, polished with Sof-Lex Pop On discs and Sof-Lex Spirals discs, resulted in lower values of surface roughness. ${ }^{27}$ For Filtek Z350 XT resin composite, the use of the silicon sandpapers was necessary to standardize the initial surface roughness of the group. To simulate the pressure exercised in clinical care, the same operator performed the groups. ${ }^{45}$

Some studies showed that the use of polyester strip in the resin composite sample preparation exhibited lower roughness and satisfactory gloss. ${ }^{6.16 .20 .23}$ However, another study showed that the surface roughness value increased for Filtek Z350 XT resin composite samples polished with the Sof-Lex Spiral discs. ${ }^{22.31}$

For the acrylic resin group, with greater roughness, ${ }^{51}$ studies show the superiority of mechanical polishing using a bench vise associated with finishing and polishing materials when compared to the finishing and polishing systems used by the clinician. For this study, the initial $\mathrm{Ra}$ of the acrylic resins in the different groups presented values above what is considered as limit of surface roughness found in the literature of $0.2 \mu \mathrm{m}{ }^{4}$ after being polished with the two types of polishing systems, and after brushing these values had a significant increase.

The Sof-Lex Spiral discs according to the manufacturer are elastomeric wheels impregnated with powdered aluminum oxide particles and consists of a single system with a universal design that facilitates the finishing and polishing in all regions of the tooth. The 
system consists of two tips, or two steps, where the colors define which one is used for finishing and polishing. In this study, the polishing system Sof-Lex Spiral discs presented a greater roughness in all the materials tested, when compared to the polishing system Sof-Lex Pop On, except for the bis-acryl resin Structur 3 group, which maintained the same initial roughness value for both types of polishing. This significant increase in surface roughness in the polished samples may be due to the aluminum oxide particles present in their composition, which are not hard enough to produce a smoother and smoother surface. ${ }^{43}$ In the literature, it was found that the planar movement or alternative movement, in the use of finishing and polishing techniques, was the one that presented lower surface roughness values. ${ }^{12}$ Due to this, it was the movement used in all samples of this in vitro study.

For the abrasion test, 50.000 cycles were performed on the simulated brush machine, simulating an in vivo time in an average of 1 year of brushing. ${ }^{5.28 .29 .40}$ periods that was considered as capable of a temporary restoration remain in the oral cavity, at the patient's option almost always. This procedure consists in the abrasion between 3 bodies, where it is inserted, an abrasive between the brush and the sample is the "in vitro" test that most closely resembles the oral condition, to evaluate the wear of the materials, and at the end, the surface wear reading was performed through the Hommel Tester profiler. ${ }^{28.29 .32 .40 .}$

According to the literature, a material can be evaluated for abrasion resistance through loss of mass and surface smoothness after a certain period of brushing. ${ }^{8}$ The simulated brushing machine abrasion test provides contact between brush bristles and dentifrice, the profiler is used to evaluate the wear information, the formation of grooves and the average amount of material removed. ${ }^{16.17}$

A study in which the effect of the mechanical brushing time with dentifrices of different abrasives on the color change and the surface roughness of the composite resin was evaluated, showed that the surface roughness of the composite resin Z350 XT was not influenced by the 
brushing time, mechanical properties, and the abrasiveness of the dentifrice to the surface roughness. ${ }^{8.32 .34,35}$

Contrary to this study, the literature shows different results for the polishing performed with the Sof-Lex Spiral discs, which evaluated the effect of different surface treatment methods on the surface roughness and color stability of prosthodontic materials. ${ }^{20}$

In this study, the control group of the acrylic resin resulted in higher values of surface roughness, and after polishing the values showed no significant statistical difference, unlike the abrasion procedure that, for all the materials tested, the resin acrylic group that was polished with Sof-Lex Spiral discs obtained the highest surface roughness after brushing. For surface wear, it was also the material that presented higher values among all the materials tested.

For the present study, the results of surface wear values of the tested bis-acryl resins (Protemp 4 and Structur 3) were very close to the values obtained in the Z350XT composite resin group, which is a nanofilled composite according to the manufacturer, and the material that underwent less superficial wear after simulated brushing. The Protemp 4 bis-acryl resin is also, according to the manufacturer, a composite with exclusive nanofilled technology. According to the literature, composites with nanofilled technology tend to wear out less when compared to composites with nanohybrid technology, ${ }^{29}$ which may justify the results found in the present study, where the most used bis-acryl resin was the Structur 3 (a nanohybrid composite according to the manufacturer).

Based on the results of the present study, as a clinical indication, in cases that require a longer stay in the oral cavity, the Protemp 4 bis-acryl resin may be the best option, as it has a higher surface wear resistance, but suggests finishing and polishing complementing its use to improve its initial roughness.

The Structur 3 bis-acryl resin does not require the use of the polishing system after it has been made, its surface roughness is below $0.2 \mu \mathrm{m}$ (according to the results obtained in the 
present study), only gauze with alcohol is sufficient (as recommended by the manufacturer), however, it suffers greater surface wear when compared to the Protemp 4.

Of the two polishes tested, despite the practicality of the Sof-Lex Spiral system because it has two granulations, requires more work dynamics because it can cause scratches on the material when finished and polished, compared to the Sof-Lex Pop On system, which has four different granulations. It is still more laborious because it requires a longer working time, even so, it is still the polishing system that has obtained satisfactory results in the bisacryl resins tested.

For the next research, complementary to the present, a more practical "in vitro" study analyzing other types of polishing systems will be performed, however, involving a single system which serves both the anterior and posterior teeth, associated or not to diamond pastes, with the intention to facilitate the clinical day-to-day.

\section{CONCLUSION}

By polishing it is possible to improve the surface roughness of the resinous materials, however, the technique, the operator, the materials to be polished and the finishing and polishing system are directly correlated. For the present study, the system that obtained the best results was the Sof-Lex Pop On discs, and the bis-acryl resin that presented the lowest Ra number was the Structur 3 bis-acryl resin. For surface wear, the Structur 3 bis-acryl resin showed higher values compared to the results of the Protemp 4 bis-acryl resin group, which, in turn, showed surface wear values close to that of the Z350 XT composite resin group. 


\section{REFERENCES}

1. Aykent F. Yondem I. Ozyesil AG. Gunal SK. Avunduk MC. Ozkan S. Effect of different finishing techniques for resotrative materials on surface roughness and bacterial adhesion. J Prosthet Dent 2010; 103:221-7.

2. Avsar A. Yuzbasioglu E. Sarac D. The effects of finishing and polishing techniques on the surface roughness and the color of nanocomposite resin restorative materials. Adv Clin Exp Med 2015 Sep; 24(5): 881-90.

3. Blalock JS, Cooper JR. A tecnique for effective shade modification of provisional restoration. J Prosthet Dent 2011; 105: 347-348.

4. Bollen CM. Lambrechts P. Quirynen M. Comparison of surface roughness of oral hard materials to the threshold surface roughness for bacterial plaque retention: A review of the literature. Dent Mater 1997 Jun;13: 258-69.

5. Buchalla W. Attin T. Hellwing E. Brushing abrasion of luting cements under neural and acidic conditions. Oper Dent 2000 Nov-Dec;25(6): 482-7.

6. Carneiro PMA. Ramos TM. Azevedo CS de. Lima E de. Souza SHJ de. Turbino ML. Cesar $\mathrm{PF}$. Matos $\mathrm{AB}$. Influence of finishing and polishing techniques and abrasion on transmittance and roughness of composite resins. Oper Dent 2016;41(6): 634-641.

7. Celik C. Arhun N. Yamanel K. Clinical evaluation of resin-based composites in posterior restoratives: 12 mouth results. Eur J Dent 2010 Jan; 4(1): 57-65.

8. Chimello DT. Palma-Dibb RG. Corona SAM. Lara EHG. Assessing wear and surface roughness of different composite resins after toothbrusing. Materials Research 2001;4(4): 285-289.

9. Da Cunha LF. Mondelli J. Auersvald CM. Gonzaga CC. Mondelli RFL. Correr GM. et al. Endocrown with Leucite-Reinforced Ceramic: Case of Restoration of Endodontically Treated Teeth. Case Reports in Dentistry 2015; (2015): Oct 18: 750313. 
10. Egle M. Egle I. Viktorija N. In vitro color and roughness stability of different temporary restorative materials. Stomatologia. Baltic Dental and Maxillofacial Journal 2016;18(2): 66-72.

11. Endo T. Finger WJ. Kanehira M. Utterodt A. komatsu M. Surface texture and roughness of polished nanofill and nanohybrid resin composites. Dent Mater J 2010;29: 213-23.

12. Fruits TJ. Miranda FJ. Coury TL. Effects of equivalent abrasive grit sizes different polishing motions on selected restorative materials. Quintessence Int 1996; 27: 279-85.

13. Ghaffari R. Hamedi-rad F. Effect of silver nano-particles in tensile strength of acrylic resins. J Dent Res Clin Dent Prospects 2015 Winter; 9(1): 40-43.

14. Guller Au. Kurt S. Kulunk T. Effects of various finishing procedures on the staining of provisional restorative materials. J Prosthet Dent 2005; 93: 453-58.

15. Hammond BD, Cooper JR, Lazarchik DA. Predictable repairo f provisonal restorations. J Esthet Restor Dent 2009; 21: 19-25.

16. Hossam AE. Rafi AT. Ahmed AS. Sumanth CR. Surface topography of composite restorative materials following ultrasonic scaling and its impact on bacterial plaque accumulation. An in-vitro SEM study. J Int Oral Health 2013 Jun;5(3): 13-19.

17. Imfeld T. Comparison of the mechanical effects of a toothbrush and standard abrasive on human and bovine dentine in vitro. J Clin Dent_2001;12(4):92-6.

18. Jung M. Eichelberger k. Klimek J. Surface geometry of four nanofilter and one hybrid composite after one-step and multiplique-step polishing. Oper Dent 2007;32(4): 347-55.

19. Kakaboura A. Fragouli M. Rahiotis C. Silikas N. Evaluation of surface characteristics of dental composites using profilometry. scanning electron. atomic force microscopy and gloss-meter. J Mater Sci Med 2007; 18: 155-63. 
20. Köroglu A. Sahin O. Dede Ö. Yilmaz B. Effect of different surface treatment methods on the surface roughness and color stability of interim prosthodontic materials. J Prosthet Dent 2016 Apr;115(4): 447-55.

21. Kumari RV. Nagaaj H. Siddaraju K. Poluri RK. Evaluation of effect of surface polishing. oral beverages and food colorants on color stability and surface roughness of nanocomposite resins. J Int Oral Health 2015 Jul; 7(7): 63-70.

22. Kurbad A. Planning and predictability of clinical outcomes in esthetic rehabilitation. Int $\mathbf{J}$ Comput Dent 2015; 18(1): 65-84.

23. Lambrechts P. Debels E. Landuyt KV. Peumans M. Meerbeek BV. How to simulate wear? Overview of existing methods. Dent Mater 2006 Aug;22(8): 693-70.

24. Lu H. Roeder LB. Powers JM. Effect of polishing systems on the surface roughness of microhybrid composites. J Esthet Rest Dent 2003;15(5): 297-303.

25. Madhayastha PPS. Naik DG. Srikant N. Kotian R. Bhat KM. Effect of finishing/polishing techinques and time on surface roughness of silorane and methacrylate based restorative materials. Oral Health Dent Manag 2015;14: 212-8.

26. Maresca C. Pimenta L. Heymann HO. Ziemiecki TL. Ritter AV. Effect of finishing instrumentation on the margin integrity of resin-based composite restorations. J Esthet Restor Dent 2010 Apr; 22(2): 104-13.

27. Mohammed SA. Mensudar R. Venkatachalam P. Paramasivam V. Arunajatesan S. Vridhachalam GS. Evaluation of surface roughness of three different composite resins with three different polishing systems. J Conservt Dent 2016 Mar-Apr; 19(2): 171-174.

28. Mondelli RF. Wang L. Garcia FC. Prakki A. Mondelli J. Franco EB. et al. Evaluation of weight loss and surface roughness of compomers after simulated tootbrushing abrasion test. J Appl Oral Sci 2005;Jun;13(2): 131-5.24. 
29. Oliveira GU. Mondelli RFL. Rodrigues MC. Franco EB. Ishikiriama SK. Wang L. Impact of filler size and distribuition on roughness and wear of composite resin after simulated toothbrushing. J Appl Oral Sci 2012; Sep-Oct; 20(5): 510-516.

30. Passanezi E. Damante CA. Rezende MLR. Greghi SLA. Lasers in periodontal therapy. Periodontology 2000 2015;Vol 67: 268-291.

31. Patel B. Chhabra N. Jain D. Effect of different polishing systems on the surface roughness of nano-hybrid composites. J Conservt Dent 2016 Jan-Feb; 19(1): 37-40.

32. Prakki A. Cilli R. Mondelli RF. Kalachandra S. In vitro wear. surface roughness and hardness of propanal-containing and diacetyl-containing novel composites and copolymers based on bis-GMA analogs. Dent Mater 2008;24: 410-417.

33. Rishi DY. Deepak R. Divya J. Rachit M. A comparative analysis of different finishing and polishing devices on nanofilled. microfilled. and hybrid composite: A scanning Electron Microscopy and Profilometric study. Int J Clin Pediatr Dent 2016 Jul-Sep; 9(3): 201-208.

34. Roselino LM. Chinelatti MA. Alandia-Román CC. Souza FCPP. Effect of brushing time and Dentifrice Abrasiveness on Color Change and Surface Roughness of Resin Composites. Braz Dent J 2005; 5(26).

35. Roselino LM. Chinelatti MA. Alandia-Román CC. Pires FCS. Effect of brushing time and dentifrice abrasiveness on color change and surface roughness of resin composites. Braz Dent J 2015 Oct;26(5): 507-13.

36. Rutkünas V. Sabaliauskas V. Mizutami H. Effects of different food colorants and polishing techniques on color stability of provisional prosthetic materials. Dent Mater J 2010;29(2): 167-76.

37. Schiavetti R. de Vico G. Casucci A. Covello F. Ottria L. Sannino G. Barlattani A. Control and reduction of peak temperature in self-curing resins. Oral Implantol (Rome) 2009 JulSep; 2(3): 21-26. 
38. Schwedhelm ER. Direct technique for the fabrication of acrylic provisional restorations. J Contem Dental Pract 2006; (7):157-73.

39. Sen D. Göller G. Issever H. The effect of two polishing pastes on the surface roughness of bis-acryl composite and methacrylate-based resins. J Prosthet Dent 2002 Nov; 88(5): 52732.

40. Soares AF. Bombonatti JF. Alencar MS. Consolmagno EC. Honório HM. Mondelli RF. Influence of $\mathrm{pH}$. bleaching agentes. and acid etching on surface wear of bovine enamel. J Appl Oral Sci 2016 Jan-Feb; 24(1):24-30.

41. Strassler H. Lowe RA. Chair side resin-based provisional restorative materials for fixed prosthodontics. Compe of Education in Dentistry. 2011;32(9): 10-9.

42. Swift J. Perdigão J. Effects of bleaching on teeth and restorations. Compend Contin Educ Dent. 1998 Aug; 19 (8): 815-20.

43. Turssi CP. Magalhães CS. Serra MC. Rodrigues Junior AL. Surface roughness assessment of resin based materials during brushing preceded by $\mathrm{pH}$ cycling simulations. Oper Dent $2001 ; 26: 576-84$.

44. Ulker M. Ulker EH. Zortuk M. Bulbul M. Tuncdemir RA. Bilgim SM. Effects if current provisional restoration materials on the viability of fibroblasts. European Journal of Dentstry. 2009 Abr; 3:114-19.

45. Venturini D. Cenci MS. Demarco FF. Camacho GB. Powers JM. Effect of polishing techniques and time on surface roughness. hardness and microleakage of resin composite restorationas. Oper Dent 2006; 31: 11-7.

46. Yap AU. Lye KW. Sau CW. Surface characteristics of tooth-colored restoratives polished utilizing different polishing systems. Oper Dent 1997 Nov-Dec:22(6): 260-5.

47. Yap AU. Sau CW. Lye KW. Effects of finishing/polishing time on surface characteristics of tooth - colored restoratives. J Oral Rehabil 1998 Jun;25(6): 456-61. 
48. Young HM. Smith CT. Morton D. Comparative in vitro evaluation of two provisional restorative materials. J Pros Dent 2001 Fev; 2(85):129-32.

49. Waerhaug J. Temporary restorations: advantages and disadvantages. Dent Clin North Am. 1980; 24: 305-16.

50. Wassel RW. George GS. Ingledew RP. Steele JG. Crows and other extra-coronal restorations: Provisional Restorations. British Dental Journal 2002 Jun; 11(192); 619-29.

51. Zissis AJ. Polyzois GL. Yannikakis SA. Harrison A. Roughness of denture materials: a comparative study. Int J Prosthodont 2000 Mar-Apr;13(2): 136-40. 

3 DISCUSSION 



\section{DISCUSSION}

The available trademarks used in this study were: two bis-acryl resins (Protemp 4 and Structur 3), a chemically activated acrylic resin (Dencor) and a nanofilled resin composite (Filtek Z350 XT). As they are different materials, with different compositions, the surface roughness values at all times between the materials would be different, but the purpose of this study was to evaluate a finishing and polishing system that offers better surface roughness results for the tested bis-acryl resins.

Although provided by the same manufacturer, the finishing and polishing systems used in this study were consisted of discs (Sof-Lex Pop On) of four granulations or discs (Sof-Lex Spiral) of two granulations. As observed in the present study, both systems were able to to reduce the surface roughness. However, the Sof-Lex Pop On showed a better overall behavior. Each system depends on its abrasive power, ${ }^{8.19 .36 .45 .46 .47}$ they are basically divided into the following categories: diamond and multilayer tips, abrasive rubbers, silicon tips, discs and abrasive strips, felt disks, silicon carbide brush and diamond pastes.

Finishing and polishing procedures in restorations with acrylic resins, resin composites and bis-acryl is important to the clinical longevity of the restoration, indicating that it is satisfactory when it results in a surface that presents esthetics, smoothness, brightness and preservation of periodontal tissues. ${ }^{4.6 \cdot 10.21 .25}$ However, the surface roughness is also correlated with the biofilm accumulation, extrinsic pigmentation, abrasiveness and material wear. ${ }^{1.4 .23 .24}$ The surface roughness of a material that does not promote periodontal disease due to biofilm accumulation ideally would be equal to or less than $0.2 \mu \mathrm{m} .{ }^{4}$

In the present study, the bis-acryl resin Protemp 4 presented Ra values higher than $0.2 \mu \mathrm{m}$. This value may suggest that the material is more vulnerable to biofilm accumulation, ${ }^{4}$ which is in agreement with the literature that presented even higher values of Ra. ${ }^{20}$ After 
polishing with Sof-Lex Pop On discs and Sof-Lex Spiral discs, the Ra decreased considerably, although after brushing it did not show significant statistical difference, despite showing increased values.

For this study, bis-acryl resin Structur 3 group showed that the initial Ra values were equal to or less than $0.2 \mu \mathrm{m}$, which may suggest a lower biofilm accumulation and periodontal consequences, ${ }^{4}$ although there was an increase in Ra value for the group polished with SofLex Spiral discs, without statistically significant difference when compared to the other polishing system tested the Sof-Lex discs and the superficial wear after brushing for both groups.

However, among the groups of the bis-acryl resins tested, Structur 3 obtained the best results regarding surface roughness, but suffered more wear when submitted to the abrasion procedure when compared to Protemp 4.

The polishing of the samples of this study was performed 24 hours after the preparation because some studies have shown that there is a better marginal seal if the polishing is delayed for this time, except the bis-acryl group in which the polishing procedure was realized after the setting time according to the manufacture instructions. Other authors reported that immediate finishing and polishing might result in plastic deformation of the composite resin. ${ }^{11.21 .25}$

The control group Filtek Z350XT resin composite, polished with Sof-Lex Pop On discs and Sof-Lex Spirals discs, resulted in lower values of surface roughness. ${ }^{27}$ For Filtek Z350 XT resin composite, the use of the silicon sandpapers was necessary to standardize the initial surface roughness of the group. To simulate the pressure exercised in clinical care, the same operator performed the groups. ${ }^{45}$

Some studies showed that the use of polyester strip in the resin composite sample preparation exhibited lower roughness and satisfactory gloss. ${ }^{6.16 .20 .23}$ However, another study showed that the surface roughness value increased for Filtek Z350 XT resin composite samples 
polished with the Sof-Lex Spiral discs. ${ }^{22.31}$

For the acrylic resin group, with greater roughness, ${ }^{51}$ studies show the superiority of mechanical polishing using a bench vise associated with finishing and polishing materials when compared to the finishing and polishing systems used by the clinician. For this study, the initial $\mathrm{Ra}$ of the acrylic resins in the different groups presented values above what is considered as limit of surface roughness found in the literature of $0.2 \mu \mathrm{m}^{4}$ after being polished with the two types of polishing systems, and after brushing these values had a significant increase.

The Sof-Lex Spiral discs according to the manufacturer are elastomeric wheels impregnated with powdered aluminum oxide particles and consists of a single system with a universal design that facilitates the finishing and polishing in all regions of the tooth. The system consists of two tips, or two steps, where the colors define which one is used for finishing and polishing. In this study, the polishing system Sof-Lex Spiral discs presented a greater roughness in all the materials tested, when compared to the polishing system Sof-Lex Pop On, except for the bis-acryl resin Structur 3 group, which maintained the same initial roughness value for both types of polishing. This significant increase in surface roughness in the polished samples may be due to the aluminum oxide particles present in their composition, which are not hard enough to produce a smoother and smoother surface. ${ }^{43}$ In the literature, it was found that the planar movement or alternative movement, in the use of finishing and polishing techniques, was the one that presented lower surface roughness values. ${ }^{12}$ Due to this, it was the movement used in all samples of this in vitro study.

For the abrasion test, 50.000 cycles were performed on the simulated brush machine, simulating an in vivo time in an average of 1 year of brushing. ${ }^{5.28 .29 .40}$ periods that was considered as capable of a temporary restoration remain in the oral cavity, at the patient's option almost always. This procedure consists in the abrasion between 3 bodies, where it is inserted, an abrasive between the brush and the sample is the "in vitro" test that most closely resembles 
the oral condition, to evaluate the wear of the materials, and at the end, the surface wear reading was performed through the Hommel Tester profiler. ${ }^{28.29 .32 .40 .}$

According to the literature, a material can be evaluated for abrasion resistance through loss of mass and surface smoothness after a certain period of brushing. ${ }^{8}$ The simulated brushing machine abrasion test provides contact between brush bristles and dentifrice, the profiler is used to evaluate the wear information, the formation of grooves and the average amount of material removed. ${ }^{16.17}$

A study in which the effect of the mechanical brushing time with dentifrices of different abrasives on the color change and the surface roughness of the composite resin was evaluated, showed that the surface roughness of the composite resin Z350 XT was not influenced by the brushing time, mechanical properties, and the abrasiveness of the dentifrice to the surface roughness. ${ }^{8.32 .34,35}$

Contrary to this study, the literature shows different results for the polishing performed with the Sof-Lex Spiral discs, which evaluated the effect of different surface treatment methods on the surface roughness and color stability of prosthodontic materials. ${ }^{20}$

In this study, the control group of the acrylic resin resulted in higher values of surface roughness, and after polishing the values showed no significant statistical difference, unlike the abrasion procedure that, for all the materials tested, the resin acrylic group that was polished with Sof-Lex Spiral discs obtained the highest surface roughness after brushing. For surface wear, it was also the material that presented higher values among all the materials tested.

For the present study, the results of surface wear values of the tested bis-acryl resins (Protemp 4 and Structur 3) were very close to the values obtained in the Z350XT composite resin group, which is a nanofilled composite according to the manufacturer, and the material that underwent less superficial wear after simulated brushing. The Protemp 4 bis-acryl resin is also, according to the manufacturer, a composite with exclusive nanofilled technology. 
According to the literature, composites with nanofilled technology tend to wear out less when compared to composites with nanohybrid technology, ${ }^{29}$ which may justify the results found in the present study, where the most used bis-acryl resin was the Structur 3 (a nanohybrid composite according to the manufacturer).

Based on the results of the present study, as a clinical indication, in cases that require a longer stay in the oral cavity, the Protemp 4 bis-acryl resin may be the best option, as it has a higher surface wear resistance, but suggests finishing and polishing complementing its use to improve its initial roughness.

The Structur 3 bis-acryl resin does not require the use of the polishing system after it has been made, its surface roughness is below $0.2 \mu \mathrm{m}$ (according to the results obtained in the present study), only gauze with alcohol is sufficient (as recommended by the manufacturer), however, it suffers greater surface wear when compared to the Protemp 4.

Of the two polishes tested, despite the practicality of the Sof-Lex Spiral system because it has two granulations, requires more work dynamics because it can cause scratches on the material when finished and polished, compared to the Sof-Lex Pop On system, which has four different granulations. It is still more laborious because it requires a longer working time, even so, it is still the polishing system that has obtained satisfactory results in the bisacryl resins tested.

For the next research, complementary to the present, a more practical "in vitro" study analyzing other types of polishing systems will be performed, however, involving a single system which serves both the anterior and posterior teeth, associated or not to diamond pastes, with the intention to facilitate the clinical day-to-day. 

4 CONCLUSION 



\section{CONCLUSION}

By polishing it is possible to improve the surface roughness of the resinous materials, however, the technique, the operator, the materials to be polished and the finishing and polishing system are directly correlated. For the present study, the system that obtained the best results was the Sof-Lex Pop On discs, and the bis-acryl resin that presented the lowest Ra number was the Structur 3 bis-acryl resin. For surface wear, the Structur 3 bis-acryl resin showed higher values compared to the results of the Protemp 4 bis-acryl resin group, which, in turn, showed surface wear values close to that of the Z350 XT composite resin group. 

REFERENCES 



\section{REFERENCES}

1. Aykent F. Yondem I. Ozyesil AG. Gunal SK. Avunduk MC. Ozkan S. Effect of different finishing techniques for resotrative materials on surface roughness and bacterial adhesion. J Prosthet Dent 2010;103: 221-7.

2. Avsar A. Yuzbasioglu E. Sarac D. The effects of finishing and polishing techniques on the surface roughness and the color of nanocomposite resin restorative materials Adv Clin Exp Med. 2015 Sep; 24(5): 881-90.

3. Blalock JS, Cooper JR. A tecnique for effective shade modification of provisional restoration. J Prosthet Dent 2011; 105: 347-348.

4. Bollen CM. Lambrechts P. Quirynen M. Comparison of surface roughness of oral hard materials to the threshold surface roughness for bacterial plaque retention: A review of the literature. Dent Mater 1997 Jun;13: 258-69.

5. Buchalla W. Attin T. Hellwing E. Brushing abrasion of luting cements under neural and acidic conditions. Oper Dent 2000 Nov-Dec;25(6): 482-7.

6. Carneiro PMA. Ramos TM. Azevedo CS de. Lima E de. Souza SHJ de. Turbino ML. Cesar PF. Matos AB. Influence of finishing and polishing techniques and abrasion on transmittance and roughness of composite resins. Oper Dent 2016;41(6): 634-641.

7. Celik C. Arhun N. Yamanel K. Clinical evaluation of resin-based composites in posterior restoratives: 12 mouth results. Eur J Dent. 2010 Jan; 4(1): 57-65.

8. Chimello DT. Palma-Dibb RG. Corona SAM. Lara EHG. Assessing wear and surface roughness of different composite resins after toothbrusing. Materials Research 2001;4(4): 285-289.

9. Da Cunha LF. Mondelli J. Auersvald CM. Gonzaga CC. Mondelli RFL. Correr GM. et al. Endocrown with Leucite-Reinforced Ceramic: Case of Restoration of Endodontically Treated Teeth. Case Reports in Dentistry 2015; (2015): Oct 18: 750313. 
10. Egle M. Egle I. Viktorija N. In vitro color and roughness stability of different temporary restorative materials. Stomatologia. Baltic Dental and Maxillofacial Journal 2016;18(2): 66-72.

11. Endo T. Finger WJ. Kanehira M. Utterodt A. komatsu M. Surface texture and roughness of polished nanofill and nanohybrid resin composites. Dent Mater J 2010;29: 213-23.

12. Fruits TJ. Miranda FJ. Coury TL. Effects of equivalent abrasive grit sizes different polishing motions on selected restorative materials. Quintessence Int 1996; 27: 279-85.

13. Ghaffari R. Hamedi-rad F. Effect of silver nano-particles in tensile strength of acrylic resins. J Dent Res Clin Dent Prospects. 2015 Winter; 9(1): 40-43.

14. Guller Au. Kurt S. Kulunk T. Effects of various finishing procedures on the staining of provisional restorative materials. J Prosthet Dent. 2005; 93: 453-58.

15. Hammond BD, Cooper JR, Lazarchik DA. Predictable repairo f provisonal restorations. J Esthet Restor Dent 2009; 21: 19-25.

16. Hossam AE. Rafi AT. Ahmed AS. Sumanth CR. Surface topography of composite restorative materials following ultrasonic scaling and its impact on bacterial plaque accumulation. An in-vitro SEM study. J Int Oral Health 2013 Jun;5(3): 13-19.

17. Imfeld T. Comparison of the mechanical effects of a toothbrush and standard abrasive on human and bovine dentine in vitro. J Clin Dent_2001;12(4):92-6.

18. Jung M. Eichelberger k. Klimek J. Surface geometry of four nanofilter and one hybrid composite after one-step and multiplique-step polishing. Oper Dent 2007;32(4): 347-55.

19. Kakaboura A. Fragouli M. Rahiotis C. Silikas N. Evaluation of surface characteristics of dental composites using profilometry. scanning electron. atomic force microscopy and gloss-meter. J Mater Sci Med 2007; 18: 155-63. 
20. Köroglu A. Sahin O. Dede Ö. Yilmaz B. Effect of different surface treatment methods on the surface roughness and color stability of interim prosthodontic materials. J Prosthet Dent 2016 Apr;115(4): 447-55.

21. Kumari RV. Nagaaj H. Siddaraju K. Poluri RK. Evaluation of effect of surface polishing. oral beverages and food colorants on color stability and surface roughness of nanocomposite resins. J Int Oral Health $2015 \mathrm{Jul}$; 7(7): 63-70.

22. Kurbad A. Planning and predictability of clinical outcomes in esthetic rehabilitation. Int J Comput Dent. 2015; 18(1): 65-84.

23. Lambrechts P. Debels E. Landuyt KV. Peumans M. Meerbeek BV. How to simulate wear? Overview of existing methods. Dent Mater 2006 Aug;22(8): 693-70.

24. Lu H. Roeder LB. Powers JM. Effect of polishing systems on the surface roughness of microhybrid composites. J Esthet Rest Dent 2003;15(5): 297-303.

25. Madhayastha PPS. Naik DG. Srikant N. Kotian R. Bhat KM. Effect of finishing/polishing techinques and time on surface roughness of silorane and methacrylate based restorative materials. Oral Health Dent Manag 2015;14: 212-8.

26. Maresca C. Pimenta L. Heymann HO. Ziemiecki TL. Ritter AV. Effect of finishing instrumentation on the margin integrity of resin-based composite restorations. J Esthet Restor Dent. 2010 Apr; 22(2): 104-13.

27. Mohammed SA. Mensudar R. Venkatachalam P. Paramasivam V. Arunajatesan S. Vridhachalam GS. Evaluation of surface roughness of three different composite resins with three different polishing systems. J Conservt Dent 2016 Mar-Apr; 19(2): 171-174.

28. Mondelli RF. Wang L. Garcia FC. Prakki A. Mondelli J. Franco EB. et al. Evaluation of weight loss and surface roughness of compomers after simulated tootbrushing abrasion test. J Appl Oral Sci 2005;Jun;13(2): 131-5.24. 
29. Oliveira GU. Mondelli RFL. Rodrigues MC. Franco EB. Ishikiriama SK. Wang L. Impact of filler size and distribuition on roughness and wear of composite resin after simulated toothbrushing. J Appl Oral Sci 2012; Sep-Oct; 20(5): 510-516.

30. Passanezi E. Damante CA. Rezende MLR. Greghi SLA. Lasers in periodontal therapy. Periodontology 2000 2015; Vol 67: 268-291.

31. Patel B. Chhabra N. Jain D. Effect of different polishing systems on the surface roughness of nano-hybrid composites. J Conservt Dent 2016 Jan-Feb; 19(1): 37-40.

32. Prakki A. Cilli R. Mondelli RF. Kalachandra S. In vitro wear. surface roughness and hardness of propanal-containing and diacetyl-containing novel composites and copolymers based on bis-GMA analogs. Dent Mater 2008;24: 410-417.

33. Rishi DY. Deepak R. Divya J. Rachit M. A comparative analysis of different finishing and polishing devices on nanofilled. microfilled. and hybrid composite: A scanning Electron Microscopy and Profilometric study. Int J Clin Pediatr Dent 2016 Jul-Sep; 9(3): 201-208.

34. Roselino LM. Chinelatti MA. Alandia-Román CC. Souza FCPP. Effect of brushing time and Dentifrice Abrasiveness on Color Change and Surface Roughness of Resin Composites. Braz. Dent. J. 2005; 5(26).

35. Roselino LM. Chinelatti MA. Alandia-Román CC. Pires FCS. Effect of brushing time and dentifrice abrasiveness on color change and surface roughness of resin composites. Braz Dent J 2015 Oct;26(5): 507-13.

36. Rutkünas V. Sabaliauskas V. Mizutami H. Effects of different food colorants and polishing techniques on color stability of provisional prosthetic materials. Dent Mater J. 2010;29(2): 167-76.

37. Schiavetti R. de Vico G. Casucci A. Covello F. Ottria L. Sannino G. Barlattani A. Control and reduction of peak temperature in self-curing resins. 2009 Jul-Sep; 2(3): 21-26. 
38. Schwedhelm ER. Direct technique for the fabrication of acrylic provisional restorations. J Contem Dental Pract. 2006; (7):157-73.

39. Sen D. Göller G. Issever H. The effect of two polishing pastes on the surface roughness of bis-acryl composite and methacrylate-based resins. J Prosthet Dent 2002 Nov;88(5): 527-32.

40. Soares AF. Bombonatti JF. Alencar MS. Consolmagno EC. Honório HM. Mondelli RF. Influence of $\mathrm{pH}$. bleaching agentes. and acid etching on surface wear of bovine enamel. J Appl Oral Sci 2016 Jan-Feb;24(1):24-30.

41. Strassler H. Lowe RA. Chair side resin-based provisional restorative materials for fixed prosthodontics. Compe of Education in Dentistry. 2011;32(9): 10-9.

42. Swift J. Perdigão J. Effects of bleaching on teeth and restorations. Compend Contin Educ Dent. 1998 Aug; 19 (8): 815-20.

43. Turssi CP. Magalhães CS. Serra MC. Rodrigues Junior AL. Surface roughness assessment of resin based materials during brushing preceded by $\mathrm{pH}$ cycling simulations. Oper Dent 2001;26:576-84.

44. Ulker M. Ulker EH. Zortuk M. Bulbul M. Tuncdemir RA. Bilgim SM. Effects if current provisional restoration materials on the viability of fibroblasts. European Journal of Dentstry. 2009 Abr; 3:114-19.

45. Venturini D. Cenci MS. Demarco FF. Camacho GB. Powers JM. Effect of polishing techniques and time on surface roughness. hardness and microleakage of resin composite restorationas. Oper Dent 2006;31: 11-7.

46. Yap AU. Lye KW. Sau CW. Surface characteristics of tooth-colored restoratives polished utilizing different polishing systems. Oper Dent 1997 Nov-Dec:22(6): 260-5.

47. Yap AU. Sau CW. Lye KW. Effects of finishing/polishing time on surface characteristics of tooth - colored restoratives. J Oral Rehabil. 1998 Jun;25(6): 456-61. 
48. Young HM. Smith CT. Morton D. Comparative in vitro evaluation of two provisional restorative materials. J Pros Dent. 2001 Fev; 2(85):129-32.

49. Waerhaug J. Temporary restorations: advantages and disadvantages. Dent Clin North Am. 1980;24: 305-16.

50. Wassel RW. George GS. Ingledew RP. Steele JG. Crows and other extra-coronal restorations: Provisional Restorations. British Dental Journal 2002 Jun; 11(192); 619-29.

51. Zissis AJ. Polyzois GL. Yannikakis SA. Harrison A. Roughness of denture materials: a comparative study. Int J Prosthodont 2000 Mar-Apr;13(2): 136-40. 